\title{
Ostracods of the Toarcian (Jurassic) of Peniche, Portugal: taxonomy and evolution across and beyond the GSSP interval
}

\author{
Maria Cristina Cabral, Alan R. Lord, Susana Pinto, luís V. Duarte \\ \& ANA C. AZERÊDO
}

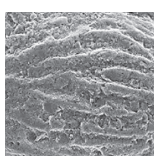

\begin{abstract}
The stratigraphical occurrence of ostracod assemblages of the uppermost Pliensbachian (emaciatum Biozone) and Lower-Middle Toarcian (polymorphum, levisoni and bifrons biozones) at Peniche, western Portugal, is reported, an interval that encompasses the Toarcian Global Boundary Stratotype Section and Point (GSSP) and the Toarcian Oceanic Anoxic Event as represented by a Carbon Isotope Excursion (CIE). The broad pattern of ostracod faunal turnover and replacement in the Peniche GSSP section before, during and after the CIE, including "survivor" and "Lazarus" species, and the stepwise extinction of metacopine ostracods is similar to that described from elsewhere in Western Europe. Assemblage composition is closest to material described from the Fastnet Basin, offshore SW Ireland, and the Mochras Farm Borehole, Wales, Great Britain. The $\delta^{13} \mathrm{C}$ record at Peniche and Mochras Farm facilitates a very refined comparison of ranges of species in common between the two sites. The species Bairdia paramolesta sp. nov. and Kinkelinella ventrocarinata sp. nov. are described. - Key words: Pliensbachian-Toarcian, ostracods, CIE, taxonomy, biostratigraphy, palaeobiogeography, Portugal.
\end{abstract}

Cabral, M.C., Lord, A.R., Pinto, S., Duarte, L.V. \& Azerêdo, A.C. 2020. Ostracods of the Toarcian (Jurassic) of Peniche, Portugal: taxonomy and evolution across and beyond the GSSP interval. Bulletin of Geosciences 95(3), 243-278 (12 figures). Czech Geological Survey, Prague. ISSN 1214-1119. Manuscript received December 20, 2019; accepted in revised form May 27, 2020; published online July 4, 2020; issued August 9, 2020.

Maria Cristina Cabral \& Ana C. Azerêdo, Instituto Dom Luiz (IDL), Faculdade de Ciências, Universidade de Lisboa, Campo Grande, C1, 1749-016 Lisboa, Portugal \& Departamento de Geologia, Faculdade de Ciências, Universidade de Lisboa, Campo Grande, C6, 1749-016 Lisboa, Portugal; mccabral@fc.ul.pt • Alan R. Lord, Senckenberg Forschungsinstitut Frankfurt, Senckenberganlage 25, D-60325 Frankfurt-am-Main, Germany • Susana Pinto, Rua Américo Vigário, 1, $1^{\circ}$ Esq, 2665-224 Malveira, Portugal • Luís V. Duarte, University of Coimbra, MARE - Marine and Environmental Sciences Centre, Department of Earth Sciences, Rua Silvio Lima, 3030-790 Coimbra, Portugal

With the formal recognition of the Global Boundary Stratotype Section and Point (GSSP) for the base of the Toarcian Stage at Peniche, western Portugal (Rocha et al. 2016), all stages of the Early Jurassic are now defined thus providing the essential stratigraphic framework for developing understanding of global environmental conditions and biota for that period of time (201.4-174.2 Ma, Ogg et al. 2016). The Toarcian stage represents a very special phase of Earth history when, to cite Xu et al. (2018, pp. 396-397): "The Toarcian stage $(\sim 183-174 \mathrm{Ma})$ is considered to be the warmest interval of the Jurassic period encompassing a transient temperature rise of up to $\sim 7{ }^{\circ} \mathrm{C}$ in mid-latitudes (Dera et al. 2011, Gradstein et al. 2012, Korte et al. 2015). The stage is also marked by one of the most intense and geographically widespread developments of anoxic/euxinic oceanic conditions of the Mesozoic era (Jenkyns 2010). This phenomenon of extreme redox changes is therefore termed the Toarcian Oceanic Anoxic Event (T-OAE, at $\sim 183 \mathrm{Ma}$ ) and is marked by large-scale organic-carbon burial in shelf-sea settings, deeper marine basins, and lakes (Jenkyns 1985, 1988; Xu et al. 2017). The T-OAE was characterized by a severe perturbation to the global carbon cycle...". We give this quotation at length because it is an efficient introduction to Toarcian times, which are currently the subject of a large and rapidly growing literature which it is not our purpose to summarize here. Current work links the growth of a late Pliensbachian cryosphere and its decline in the early Toarcian with climate change and sea level fluctuations, broadly Pliensbachian regression and early Toarcian transgression, and freshwater input into the oceans with greenhouse gases released into the atmosphere and reflected in the carbon isotope record (Ruebsam at al. 2019). This phase of the Earth history also records a widely documented mass extinction (e.g. Hallam 1961, Little \& Benton 1995, Caswell et al. 2009, Caruthers et al. 2013, Danise et al. 2013) which is clearly demonstrated in an important group 

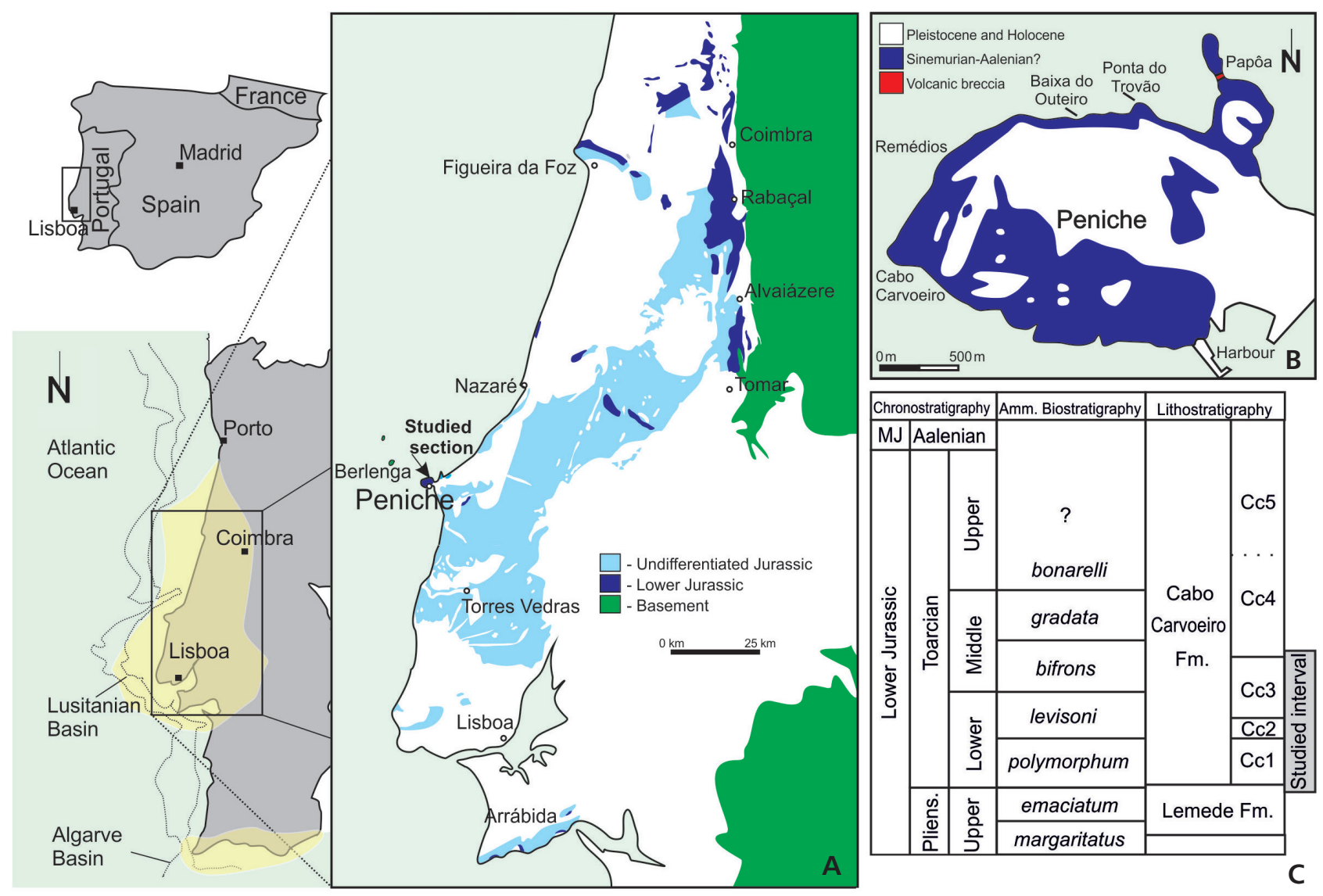

Figure 1. A - Peniche region, general location map; yellow zones: offshore area of Lusitanian and Algarve basins. $\bullet$ B - detail of Peniche Peninsula with location of Ponta do Trovão (GSSP). $\bullet$ C - chronostratigraphic, biostratigraphic (ammonite) and lithostratigraphic framework of the studied interval. Based on Duarte \& Soares (2002) and Duarte et al. (2017). Abbreviation: Fm. - Formation.

of microbiota, Ostracoda (e.g. Lord 1982, Boomer et al. 2008). We use the term Carbon Isotope Excursion (CIE) in preference to T-OAE, as the $\delta^{13} \mathrm{C}$ signal is the primary record of an event which although broadly global in scale represented fluctuations in bottom water oxygenation and allowed the existence of relatively oxygenated refugia for species that may disappear temporarily at some localities and later reappear when conditions ameliorate, the socalled "Lazarus" taxa.

The present paper describes and discusses the occurrence pattern of ostracods across the PliensbachianToarcian stage boundary (which includes the Toarcian GSSP) and through and post the CIE at Peniche, western Portugal.

\section{The uppermost Pliensbachian-Middle Toarcian section at Peniche}

The study region is located at the coastline, $80 \mathrm{~km}$ to the north of Lisbon (Fig. 1), where an almost complete Lower Jurassic to probably lowermost Middle Jurassic marl- limestone succession crops out in excellent conditions. The Peniche Peninsula succession is over $450 \mathrm{~m}$ thick and it bears a highly important geological record that, besides its international multidisciplinary relevance (e.g. Rocha et al. 2016, Duarte et al. 2017, and references therein), is one of the key sections for understanding the sedimentological evolution and stratigraphy of the Lusitanian Basin (LB). This Mesozoic western Iberian basin was controlled by the geodynamic processes leading to the North Atlantic Ocean opening and was under the influence of the western Tethys Sea, as shown by the ammonite and benthic foraminifers records. The Lower and Middle Jurassic infilling of the LB represent a post-Triassic rifting stage, characterized by increasingly marine deposition over the basin, from deep- to shallow-marine limestones and marls, dolostones and organic-rich shales, developed on a carbonate ramp depositional system (e.g. Azerêdo et al. 2003, Duarte et al. 2010, and references therein).

At Peniche, the Lower Jurassic marl-limestone deposits range in age from the (?) early Sinemurian to the late Toarcian, comprising several formations, mostly of hemipelagic nature and thus supported by ammonite 
biostratigraphy (e.g. Mouterde 1955, Duarte et al. 2018) of which only the topmost Lemede (top Pliensbachianbasal Toarcian) and part of the Cabo Carvoeiro formations (CC1 to CC4 members, Lower-Middle Toarcian) are addressed here (Duarte \& Soares 2002, Duarte 2007; Figs 1, 2). At Peniche, this interval records the Toarcian GSSP and the T-OAE, reflected in both carbon and oxygen stable isotope negative excursions and important changes in the biotic record, such as for calcareous nannofossils, dinoflagellates, foraminifers, ostracods and brachiopods (e.g. Hesselbo et al. 2007; Suan et al. 2008, 2010; Mattioli et al. 2009; Cabral et al. 2011, 2013; Comas-Rengifo et al. 2015; Rita et al. 2016; Rocha et al. 2016; Correia et al. 2017; Duarte et al. 2017; Fantasia et al. 2019). The sharpest change is recorded in the ostracod group, with extinction of the Metacopina (Cabral et al. 2011, 2013; Rocha et al. 2016). The Lower Toarcian of Peniche shows two important negative carbon isotope events which can be globally correlated (Hesselbo et al. 2007, Littler et al. 2010, Fantasia et al. 2019) (Fig. 2). The first event corresponds to Horizon 1 of Hesselbo et al. (2007, figs 2, 3); the second event, between horizons 2 and 3 of Hesselbo et al. (2007, figs 2,3) is the most important, hereafter referred as the CIE; it is particularly well defined and coincides with the early T-OAE. At the same time, this interval displays evidence of marked sedimentary changes. The Pliensbachian-Toarcian transition marks a $2^{\text {nd }}$ order regressive-transgressive discontinuity over the LB (Duarte 2007, Duarte et al. 2010), where the onset of the CIE corresponds to clear basin wide facies changes (e.g. Duarte 1997, Duarte et al. 2004, Pittet et al. 2014, RodríguezTovar et al. 2017, Fantasia et al. 2019). At Peniche, these changes include the occurrence of siliciclastic deposits showing turbidite features (Wright \& Wilson 1984, Duarte 1997), within an otherwise regular marl-limestone succession, increasingly more limestone dominated upwards.

The levels studied for ostracods correspond to the emaciatum (extreme top), polymorphum, levisoni and bifrons ammonite biozones (Figs 1,2). The emaciatum and extreme base of polymorphum biozones (top of Lemede Formation) are mostly represented by open marine limestones, with abundant ammonites and belemnites. The polymorphum Biozone encompasses the $\mathrm{CC} 1$ member $(\mathrm{mb})$ also reflecting open marine depositional conditions, shown by highly fossiliferous greyish marls and marly limestones, with ammonites, belemnites, brachiopods, bivalves and Zoophycos sp. The lower part of the levisoni Biozone (CC2 mb) is a grey marl-dominated interval, much poorer in macrofossils, mainly ammonites and a few brachiopods, and exhibits several lenticular siliciclastic facies enriched in wood fragments. The upper part of levisoni through most of the bifrons Biozone (CC3 mb) marks the disappearance of the siliciclastic facies, being characterized by a heavily bioturbated marl-limestone alternation enriched in ammonites with the latter lithology increasing upwards. The uppermost part of the bifrons Biozone (base of $\mathrm{CC} 4 \mathrm{mb}$ ) is dominated by a marly package, but upwards the unit shows increasingly common shallower water limestones (references cited above; Fig. 2).

\section{Material and methods}

Forty seven samples from the studied section (Fig. 2) were analysed using standard micropalaeontological techniques. Along the section the sampling was focused on marl levels and its frequency higher at the Pliensbachian-Toarcian boundary, CIE interval and member boundaries.

Approximately $300 \mathrm{~g}$ of each sample were dried for 24 hours and then treated with kerosene and when disaggregated the sample was washed on 150 and $63 \mu \mathrm{m}$ sieves. The $150 \mu \mathrm{m}$ fraction was completely picked and identifiable species counted. The $150-63 \mu \mathrm{m}$ fraction was inspected for small adult species.

The ostracod material is poorly preserved and often crushed, with Pliensbachian assemblages even less well preserved than Toarcian. Better preserved material is available from inland sections at Rabaçal (also known as Zambujal in literature) and Boca da Mata (Alvaiázere region), the former exposes all the Toarcian and the latter exposes Upper Toarcian to Aalenian (Duarte 1997, Pinto 2008, Cabral et al. 2013). In order to adequately figure Kinkelinella ventrocarinata sp. nov. we have included material from Rabaçal. Unless otherwise stated, numbers of specimens given under Material refer to Peniche and the term Occurrence refers to records from Peniche. For reasons of preservation it was not possible to make reliable assessments of relative species abundances, for example, in better preserved material it was possible to differentiate between 3 morphospecies of Bairdiacypris, but in many cases it was only possible to identify the genus.

Type and figured material deposited in the Senckenberg Museum, Frankfurt am Main.

Abbreviations: $\mathrm{C}=$ carapace $(\mathrm{s}) ; \mathrm{V}=\operatorname{valve}(\mathrm{s}) ; \mathrm{LV}=$ left valve; $\mathrm{RV}=$ right valve; $\mathrm{L}=$ length in $\mathrm{mm} ; \mathrm{h}=$ height in $\mathrm{mm}$.

\section{The ostracods - Systematic Palaeontology}

Ostracods of Early Jurassic age are reasonably well-known from Northern and Western Europe (see for example Arias 2006 for a list of species and literature) and assemblages from the Pliensbachian and Toarcian of Peniche have been briefly and partially reported by Pinto et al. (2007) and Rocha et al. (2016).

All the species recorded are figured (Figs 3-10) and their biostratigraphical distribution shown in Fig. 11; for reasons 
of preservation it was not possible to make absolute counts of numbers of specimens in species, the total given for each species below are for specimens where we are certain of the identification and therefore represent minimum numbers. For the same reason even relative species abundances are impossible to estimate with any reliability. The preservation problem is demonstrated in Fig. 11 by the 'Unidentifiable' column on the right.

In the section below we mostly focus on taxa that are new or of importance for biostratigraphical and palaeobiogeographical reasons. Synonymy lists are limited to the first naming of the species and key references in Iberia.

Class Ostracoda Latreille, 1806

Subclass Myodocopa Sars, 1866

Order Halocyprida Dana, 1852

Suborder Cladocopina Sars, 1866

Superfamily Cladocopoidea Sars, 1866

Family Polycopidae Sars, 1866

\section{Genus Polycope Sars, 1866}

Type species. - Polycope orbicularis Sars, 1866.

Remarks. - In Peniche Polycope occurs in the emaciatum, polymorphum and bifrons biozones, most commonly in the latter zone, but is essentially absent from the levisoni Biozone including the CIE. Most are too poorly preserved to identify at species level. A single specimen (Fig. 3A) comparable to P. cerasia Blake, 1876 described from the Hettangian-Sinemurian of Yorkshire, Great Britain was recorded in the polymorphum Biozone. In emaciatum and polymorphum biozones 15 specimens, adult $\mathrm{C}$ and $\mathrm{V}$ (Fig. 3B), are identified as Polycope cincinnata Apostolescu, 1959 described from the Pliensbachian of the Paris Basin. Abundant ( $>150 \mathrm{C}$, mostly adults) unidentifiable Polycope specimens, especially common in the bifrons Biozone, are referred to Polycope spp.

Subclass Podocopa Sars, 1866

Order Platycopida Sars, 1866

Suborder Platycopina Sars, 1866

Superfamily Cytherelloidea Sars, 1866

Family Cytherellidae Sars, 1866

\section{Genus Cytherella Jones, 1849}

Type species. - Cytherina ovata Roemer, 1841.

Remarks. - Cytherella concentrica Field, 1966 was described from the Hettangian of Dorset, Great Britain and is unusual because it has surface ornament, but was placed in Cytherella rather than Cytherelloidea because females show one posterior swelling not two as in the latter genus; our rare Toarcian material (10 C, from which 2 juveniles) from bifrons Biozone is more heavily ornamented than the type material and we cite it as Cytherella cf. C. concentrica (Fig. 3C-E).

Cytherella praecadomensis (Knitter \& Riegraf, 1984) from the Toarcian of SW Germany was originally described as belonging to Cytherelloidea, but females show a single posterior swelling as seen in Cytherella. Our material from bifrons Biozone (Fig. $3 \mathrm{~F}-\mathrm{K}$ ) is abundant ( $>350$ specimens, mostly juvenile and adult V), similar to the type material and the specimens figured by Boomer (1992) from southern Great Britain. However, it differs from material figured by Ainsworth (1986, pl. 1, figs 14-19) under the name ?Cytherella depressum sp. nov., regarded as a synonym of C. praecadomensis by Boomer (1992), in which female RV have more rounded dorsal margins.

Cytherella toarcensis Bizon, 1960 from the Toarcian of Paris Basin is characterized by its oval outline and a depression corresponding to the adductor muscle scars. The material from Peniche (Fig. 3L-P) is very similar to specimens from the type area and elsewhere in France but less similar to younger Toarcian material from other localities in Portugal and Spain (Boomer et al. 1998, Exton \& Gradstein 1984, Arias \& Lord 1999a).

In the emaciatum Biozone two specimens of Cytherella sp. (Fig. 3Q, R) were found, a large round form, the only representatives of the genus in that biozone. In contrast, C. toarcensis is the most abundant species in the CIE (in the levisoni Biozone), with $c a .70$ adult and juvenile $\mathrm{C}$ and $\mathrm{V}$.

\section{Genus Platella Coryell \& Fields, 1937}

Type species. - Platella gatunensis Coryell \& Fields, 1937.

\section{Platella toarcensis Ainsworth, 1986}

Figures 3S-U; 4A, B

1986 Platella toarcensis sp. nov.; Ainsworth, p. 293, pl. 2, figs 6-11.

Material. - Ca. $60 \mathrm{C}$ and rare V, mostly adults.

Remarks. - The genus Platella was described from the Cenozoic of Central America. P. toarcensis from the Toarcian of the Fastnet Basin is described as a weakly ornamented cytherellid (although we only see ornament in our material in Fig. 3S, T) and in our opinion is a Cytherella species, however, we do not have enough evidence to create a nom. nov. to reassign it to the genus.

Occurrence. - Toarcian, bifrons Biozone.

Order Podocopida Sars, 1866

Suborder Metacopina Sylvester-Bradley, 1961 


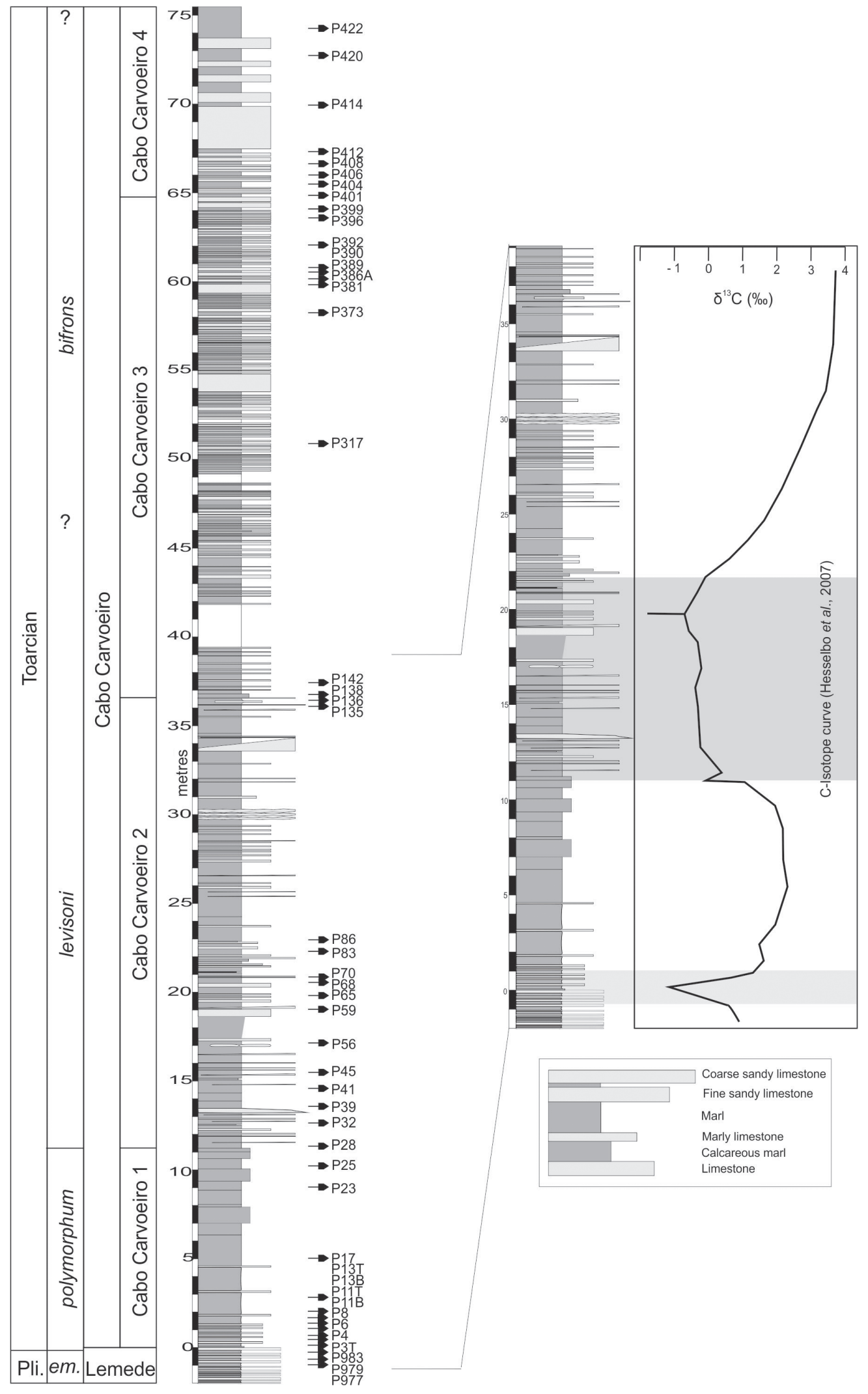

Figure 2. Peniche section - lithostratigraphic field column (based on Duarte et al. 2018) with studied samples and $\delta^{13} \mathrm{C}$ isotope curve (from Hesselbo et al. 2007, using over 2000 samples), showing two negative intervals highlighted in grey; the main negative interval referred to in this paper as CIE (between horizons 2 and 3 of Hesselbo et al. 2007, figs 2 and 3) is in darker grey. 
The Metacopina was defined, rather unsatisfactorily in the light of subsequent discoveries, as: 'Hinge distinct, simple to tripartite; muscle scar consisting of secondary scars assembled in a compact group; inner lamella narrow, poorly developed or unknown' (Sylvester-Bradley 1961, p. Q358). As originally defined the suborder is dominantly but not exclusively Palaeozoic, ranging from Ordovician to Cretaceous, however, as now recognized the group became extinct with the Superfamily Healdioidea in the Early Jurassic (early Toarcian). The Healdioidea (formerly Healdiacea) were more usefully defined by Shaver (1961, p. Q359) citing LV > RV overlap, with a platycopine style contact groove in the larger valve more strongly developed dorsally so as to resemble a hinge, and adductor muscle imprints consisting of numerous aggregate scars. A few healdioideans have ridges or weak surface ornament on their valves but most lack surface morphology (ridges, swellings) and are unornamented.

Unornamented calcite valves of ostracods are famously difficult to separate and identify at species level, given that ornament is a basic criterion used for species definition. This is especially a difficulty with the Metacopina as most lack ornament or surface morphology. Some species of Ogmoconchella show a weak netlike surface ornament when well-preserved, e.g. Ogmoconchella propinqua Malz, 1971, but this is clearly not a specific characteristic as several species are known to show similar patterns. These animals, although an extinct group, are unquestionably ostracods as appendages are known, albeit incompletely (Olempska et al. 2012). If internal information especially on muscle scar pattern is lacking then species recognition is problematic, indeed homeomorphy is unavoidable, e.g. the striking similarity between Silurian Kuresaaria gotlandica Adamczak, 1967 and Early Jurassic 'Ogmoconcha ellipsoidea (Jones)' [= Ogmoconchella aspinata (Drexler, 1958)] regarded as iterative evolution by Adamczak (1976). If internal details are lacking because of poor preservation, sediment infill or only closed carapaces preserved then there is only three-dimensional shape upon which to base species definition or identification: shape of LV, shape of RV, position of smaller RV in relation to larger LV in the carapace, dorsal and ventral views, and anterior and posterior views. Carapaces are the key because they allow recognition of isolated LV and RV as belonging together, or not. There is a further complication in that juveniles of these smooth often rounded forms are rarely distinguishable below (or even at) A-1 moult stage. In these circumstances claims of recognition of sexual dimorphism in healdiids lack credibility unless the assemblage appears potentially monospecific.

One purpose of this paper is to document the extinction of the Metacopina in relation to contemporary environmental events in the Lower Toarcian. Identification proved difficult because of preservation and infilling of valves with sediment, although in many of the late Pliensbachian-early Toarcian samples examined from Peniche the preservation of the metacopes was better than that of the cytherocopes. Given these limitations, and the fact that few people now check type material, we have opted to describe and fully figure the metacopine taxa we have recognized as species, with discussion of what they are and what they are not, and to avoid describing new healdioid species.

Superfamily Healdioidea Harlton, 1933

Family Healdiidae Harlton, 1933

\section{Genus Ledahia Gründel, 1964}

Type species. - Ledahia septenaria (Gründel, 1964).

Remarks. - Ledahia septenaria described from the Pliensbachian of NE Germany occurs in small numbers (a total of 25 adult $\mathrm{C}$ ) in the emaciatum and lower polymorphum biozones (Fig. 4C, D).

\section{Genus Ogmoconcha Triebel, 1941}

Type species. - Ogmoconcha contractula Triebel, 1941.

Figure 3. Ostracods from Peniche section, Portugal. • A - Polycope cf. P. cerasia Blake, 1876, carapace, right view, SMF Xe 23768; L=0.40, h=0.32, polymorphum Biozone, Toarcian, sample P6. • B - Polycope cincinnata Apostolescu, 1959, carapace, left view, SMF Xe 23769; L = 0.30, h = 0.25, polymorphum Biozone, Toarcian, sample P13T. C -E - Cytherella cf. C. concentrica Field, 1966, bifrons Biozone, Toarcian; C - female carapace, right view, SMF Xe 23770, $\mathrm{L}=0.57, \mathrm{~h}=0.33$, sample P386A; D - male carapace, dorsal view, SMF Xe 23771, $\mathrm{L}=0.57, \mathrm{~h}=0.32$, sample P389; $\mathrm{E}$ - male carapace, left view, SMF Xe 23772, $\mathrm{L}=0.58, \mathrm{~h}=0.31$, sample P408. $\cdot \mathrm{F}-\mathrm{K}$ - Cytherella praecadomensis (Knitter \& Riegraf, 1984), bifrons Biozone, Toarcian; F - female RV, external view, SMF Xe 23773, L = 0.66, h = 0.43, sample P406; G - female LV, external view, SMF Xe 23774, $\mathrm{L}=0.63, \mathrm{~h}=0.35$, sample P406; H - male RV, external view, SMF Xe 23775, L =0.66, h =0.40, sample P406; I - juvenile (?A-1) RV, external view, SMF Xe 23776, L = 0.58, h =0.36, sample P406. J - male carapace, dorsal view, SMF Xe 23777, L =0.65, h =0.40, sample P404; $\mathrm{K}$ - female carapace, dorsal view, SMF Xe 23778, $\mathrm{L}=0.65, \mathrm{~h}=0.41$, sample P404. $\cdot \mathrm{L}-\mathrm{P}-$ Cytherella toarcensis Bizon, 1960, levisoni Biozone, Toarcian, sample P32; $\mathrm{L}$ - female carapace, left view, SMF Xe 23779, $\mathrm{L}=0.69, \mathrm{~h}=0.47 ; \mathrm{M}$ - female RV, external view, SMF Xe 23780, $\mathrm{L}=0.69, \mathrm{~h}=0.48 ; \mathrm{N}$ - male carapace, right view, SMF Xe 23781, L = 0.70, $\mathrm{h}=0.43 ; \mathrm{O}$ - male carapace, dorsal view, SMF Xe 23782, $\mathrm{L}=0.66, \mathrm{~h}=0.44 ; \mathrm{P}$ - female carapace, dorsal view, SMF Xe 23783, $\mathrm{L}=0.67, \mathrm{~h}=0.46 . \cdot \mathrm{Q}-\mathrm{R}-$ Cytherella sp., emaciatum Biozone, topmost Pliensbachian, sample P983; Q - female RV, external view, SMF Xe 23784, $\mathrm{L}=0.81, \mathrm{~h}=0.60 ; \mathrm{R}-$ female $\mathrm{LV}$, external view, SMF Xe 23785, $\mathrm{L}=0.80, \mathrm{~h}=0.51 . \cdot \mathrm{S}-\mathrm{U}-$ Platella toarcensis Ainsworth, 1986, bifrons Biozone, Toarcian; S - female carapace, left view, SMF Xe 23786, L =0.68, h =0.34, sample P422; T - female carapace, right view, SMF Xe 23787, $\mathrm{L}=0.73, \mathrm{~h}=0.36$, sample P422; $\mathrm{U}$ - male carapace, right view, SMF Xe 23788, $\mathrm{L}=0.60, \mathrm{~h}=0.35$, sample P396. Dimensions in mm. Scale bars $=100 \mu \mathrm{m}$. 


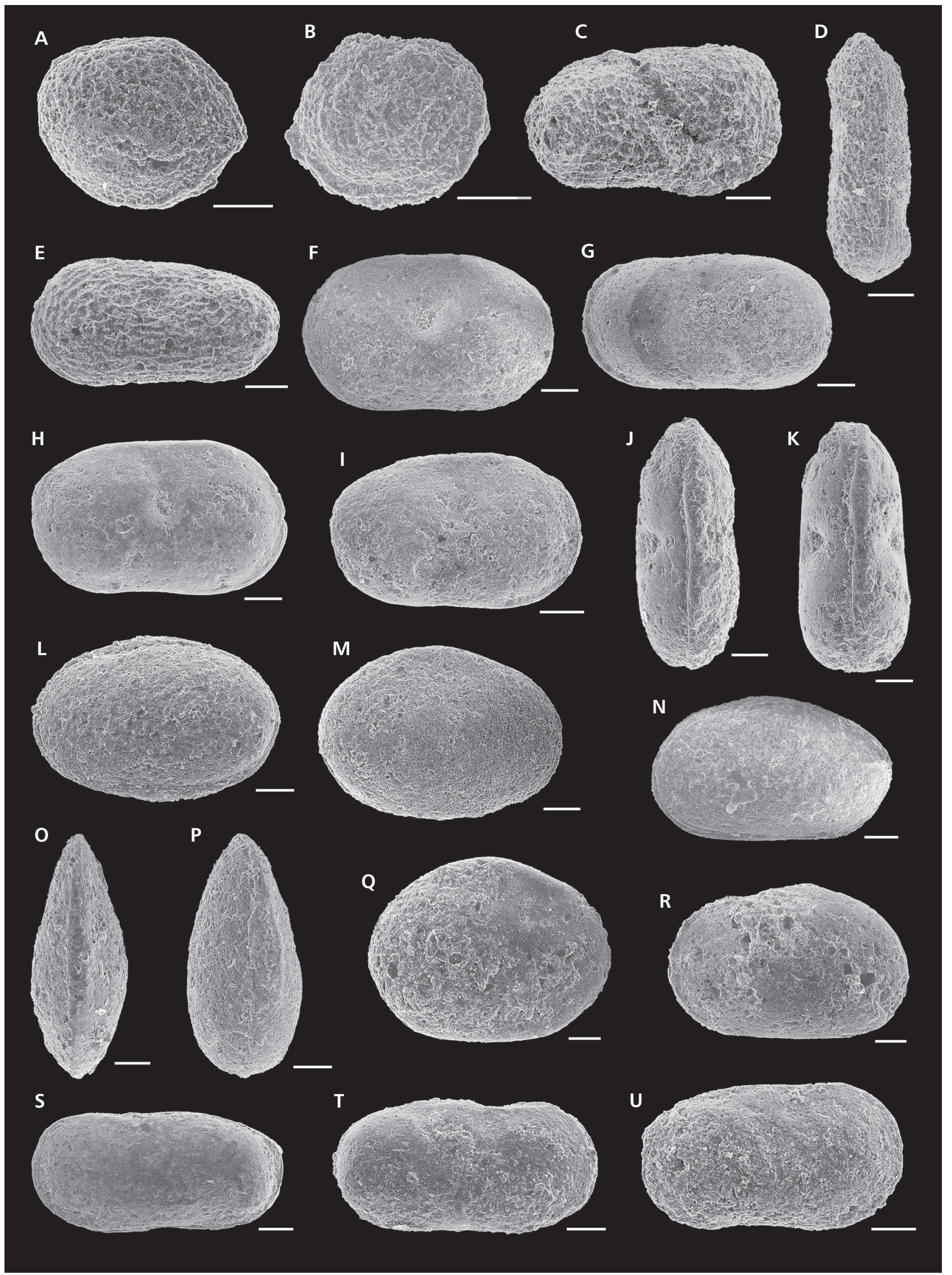


Remarks. - The genera Ogmoconcha and related Ogmoconchella, Ledahia and Pseudohealdia are the final representatives of the Suborder Metacopina, becoming extinct in the Lower Toarcian for reasons that are not entirely clear, the suborder having survived the major end Permian and end Triassic extinction events (Boomer et al. 2008). Certain Ogmoconcha species with distinctive free-margin swellings and depressions, such as $O$. inflata herein, have been separated as the genus Hermiella Kristan-Tollmann, 1977 (Kristan-Tollmann 1977, 1993), however, we prefer to retain them within Ogmoconcha, recognizing that they represent an evolutionary development of the genus with a Tethyan/Paratethyan biogeographical distribution.

\section{Ogmoconcha convexa Boomer, 1991}

Figure 4E-K

1991 Ogmoconcha convexa sp. nov.; Boomer, p. 208; pl. 1, figs $1,5,7,8$.

1998 Ogmoconcha convexa Boomer. - Boomer et al., figs $4,5$.

2009 Ogmoconcha convexa Boomer. - Boomer \& Ainsworth, pl. 1, fig. 9.

2016 Ogmoconcha convexa Boomer. - Rocha et al., fig. 4.

Material. - Ca. 450 specimens, mostly V, adults and juveniles.

Original diagnosis. - "A species of Ogmoconcha with distinctly convex lateral surfaces in dorsal view."

Description. - As Boomer (1991, p. 208), but in our material greatest width in dorsal view is usually at midlength. Internal features not known.

Remarks. - Our material is clearly conspecific with the type material from the tenuicostatum Biozone of the Mochras Farm Borehole, however, we are not convinced by the possible similarity with material from the Fastnet Basin figured by Ainsworth (1987, pl. 3, figs 3, 4, 6) as $O$. aff. O. rotunda Dreyer as recognized by Boomer (1991). Our material shows the same variation in adult size and shape that Boomer interpreted as sexual dimorphism, i.e. there appear to be two adult morphotypes that differ slightly in size and position of greatest width in dorsal view. We figure these variants as Fig. 4E-G and 4H-K. Ogmoconcha convexa also occurs in the Upper Pliensbachian, lower spinatum (= emaciatum) Biozone of Mochras Farm Borehole (Boomer, personal communication 2018), and in the Upper Pliensbachian, lower spinatun Biozone to Lower Toarcian, top tenuicostatum (= top polymorphum) Biozone of Ilminster, UK, and Fastnet Basin (Boomer \& Ainsworth 2009).

Occurrence. - Pliensbachian, emaciatum Biozone; Toarcian, polymorphum Biozone.

\section{Ogmoconcha inflata (Ainsworth, 1987)}

Figure 4L-S

1979 Ogmoconcha ambo Lord \& Moorley. - Exton, p. 62, pl. 9, figs 6, 7 .

1984 Ogmoconcha cf. ambo Lord \& Moorley. - Exton \& Gradstein, pl. 2, fig. 2.

1987 Hermiella inflata sp. nov.; Ainsworth, pp. 56, 57, pl. 2, figs 15-17, text-figs 1, 2.

1992 Ogmoconcha inflata (Ainsworth). - Boomer, p. 52, pl. 1 , fig. 5.

1998 Ogmoconcha inflata (Ainsworth). - Boomer et al., figs $4,5$.

2007 Ogmoconcha cf. intercedens Dreyer. - Pinto et al., pl. 2, figs 1-3.

2009 Hermiella inflata Ainsworth. - Boomer \& Ainsworth, pl. 1, fig. 10.

2016 Ogmoconcha inflata (Ainsworth). - Rocha et al., figs 4, 8.7.

2016 Ogmoconcha intercedens Dreyer. - Rocha et al., fig. 4.

Material. - Ca. 300 specimens, mostly adult V.

Original diagnosis. - "Carapace large, subovate to subcircular in lateral view, strongly inflated in dorsal view.

Figure 4. Toarcian ostracods from Peniche section, Portugal. - A, B - Platella toarcensis Ainsworth, 1986, bifrons Biozone, sample P422; A - male carapace, dorsal view, SMF Xe 23789, $\mathrm{L}=0.59, \mathrm{~h}=0.32$; B - female carapace, dorsal view, SMF Xe 23790, L = 0.66, $\mathrm{h}=0.35 . \bullet \mathrm{C}, \mathrm{D}-$ Ledahia septenaria (Gründel, 1964), polymorphum Biozone, sample P6; C - carapace, left view, SMF Xe 23791, L = 0.50, h = 0.28; D - carapace, dorsal view, SMF Xe 23792, $\mathrm{L}=0.50, \mathrm{~h}=0.28$. $・ \mathrm{E}-\mathrm{K}-$ Ogmoconcha convexa Boomer, 1991, polymorphum Biozone, sample P23 (E-J) and sample P11T (K); $\mathrm{E}$ - carapace, dorsal view, SMF Xe 23793, $\mathrm{L}=0.70, \mathrm{~h}=0.56 ; \mathrm{F}$ - carapace, right view, same specimen as $\mathrm{E} ; \mathrm{G}-\mathrm{LV}$, external view, SMF Xe 23794, $\mathrm{L}=0.70, \mathrm{~h}=0.55 ; \mathrm{H}$ - carapace, left view, $\mathrm{SMF} X \mathrm{Xe} 23795, \mathrm{~L}=0.68, \mathrm{~h}=0.53 ; \mathrm{I}$ - carapace, right view, same specimen as $\mathrm{H} ; \mathrm{J}$ - carapace, dorsal view, SMF Xe 23796, L = 0.70, h = 0.54; K - RV, external view, SMF Xe 23797, L = 0.64, h = 0.44. $\bullet \mathrm{L}-\mathrm{S}-$ Ogmoconcha inflata (Ainsworth, 1987), polymorphum Biozone; $\mathrm{L}$ - carapace, dorsal view, SMF Xe 23798, $\mathrm{L}=0.81, \mathrm{~h}=0.59$, sample P4; M - RV, external view, SMF Xe 23799, $\mathrm{L}=0.74, \mathrm{~h}=0.51$, sample P6; N - LV, external view, SMF Xe 23800, L = 0.80, h=0.59, sample P3T; O - LV, external view, SMF Xe 23801, L = 0.78, h=0.61, sample P6; P - RV, external view, SMF Xe 23802, $\mathrm{L}=0.80, \mathrm{~h}=0.54$, sample P4; $\mathrm{Q}$ - carapace, right view, SMF Xe 23803, $\mathrm{L}=0.68, \mathrm{~h}=0.52$, sample P23; R carapace, left view, same specimen as Q; S - RV, external view, SMF Xe 23804, L =0.67, h =0.49, sample P23. Dimensions in mm. Scale bars $=100 \mu \mathrm{m}$. 


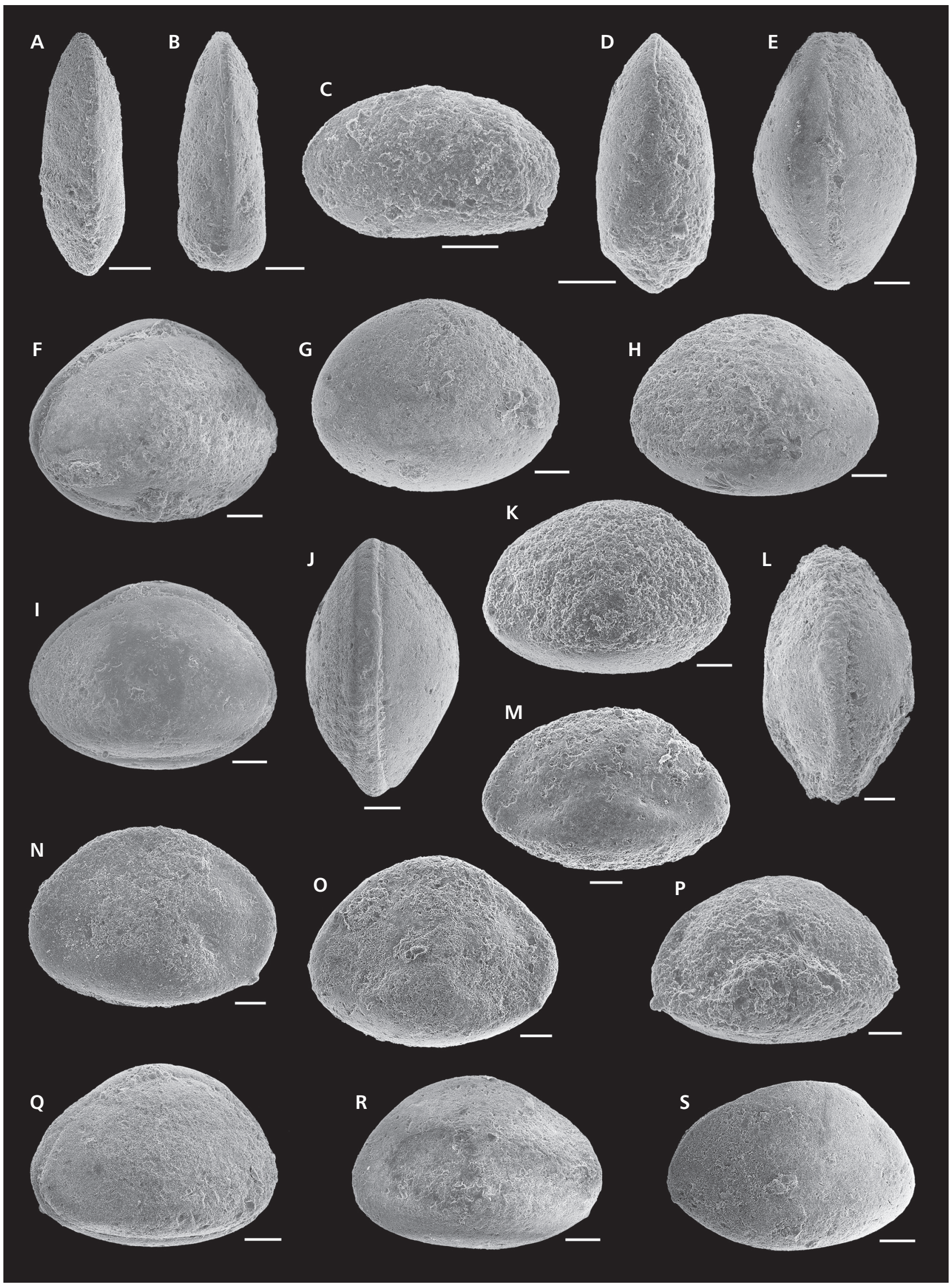


A very low moderately broad rim in an Arabic ' 3 ' pattern extends around anterior, ventral and posterior margins; between rim, two weakly formed rounded depressions situated antero-ventrally and postero-ventrally. Dorsally, rim more poorly defined, best observed in posterior view."

Description. - As Ainsworth (1987). Internal features unknown.

Remarks. - Our Toarcian material matches the description and figures of Ainsworth (1987) of the type material from the Upper Pliensbachian of the Fastnet Basin and confirms the observation that the depressions of the valve surface are less well developed in left valves than in right. We also have this species in the Pliensbachian of Peniche where the depressions and the slightly depressed connecting area beneath the dorsal margin are more clearly developed than in Toarcian specimens. Our material shows some shape variation, for example, compare LV in Fig. $4 \mathrm{~N}$ and $4 \mathrm{O}$ and $\mathrm{RV}$ in Fig. 4M and 4P, but the characteristic '3' pattern confirms the species identification. A further problem is that specimens figured in Fig. 4Q-S show the ' 3 ' pattern in the light microscope but it is not evident in the SEM figures shown here. When these characteristic depressions are weakly developed, which is commonly the case, $O$. inflata is very easily confused with $O$. intercedens (see synonymy list above). Ogmoconcha inflata also occurs in the Upper Pliensbachian (spinatum Biozone) to Lower Toarcian (tenuicostatum Biozone) of Mochras Farm Borehole and Ilminster, UK, and in the Lower Toarcian (tenuicostatum Biozone) of Fastnet Basin (Boomer \& Ainsworth 2009).

Occurrence. - Pliensbachian, emaciatum Biozone; Toarcian, polymorphum Biozone.

\section{Ogmoconcha sp. A Boomer, 1992}

Figure 5A

1992 Ogmoconcha sp. A; Boomer, pp. 52, 54, pl. 1, fig. 6a, b.

Material. -2 adult LV.
Remarks. - Boomer (1992) figures a stereo-pair of a right valve from the tenuicostatum Biozone of southern England but unfortunately not a left valve. Our material appears similar but we cannot be certain.

Occurrence. - Toarcian, polymorphum Biozone.

\section{Ogmoconcha sp.1}

Figure 5B-D

2016 Ogmoconcha cf. amalthei (Quenstedt, 1858). - Rocha et al., fig. 4.

Material. - Ca. 450 adult and juvenile V and $70 \mathrm{C}$, mostly juveniles.

Remarks. - A relatively elongate form, narrower in dorsal view than $O$. sp. 2. Internal features unknown. Lateral outline has some resemblance to that of $O$. amalthei but position of greatest length is higher in the valve ( $c f$. Triebel 1950, figs 13-17) and we prefer to leave the species in open nomenclature.

Occurrence. - Pliensbachian, emaciatum Biozone; Toarcian, polymorphum Biozone.

\section{Ogmoconcha sp. 2}

Figure 5E-H

1987 Ogmoconcha aff. O. rotunda Dreyer, 1967. - Ainsworth, pp. 57,58 , pl. 3 , figs $3,4,6$.

2016 Ogmoconcha cf. hagenowi (Drexler, 1958). - Rocha et al., figs 4, 8.1.

Material. -Ca. $300 \mathrm{~V}$ and $80 \mathrm{C}$, adults and juveniles.

Remarks. - A rounded, small form with a lateral outline resembling that of $O$. convexa, of which it may be a juvenile form. Internal features unknown. Compared to O. hagenowi in Rocha et al. (2016) but hagenowi is upper Hettangian-Lower Sinemurian and has a heavily calcified and robust carapace.

Figure 5. Toarcian (polymorphum Biozone) ostracods from Peniche section, Portugal. • A - Ogmoconcha sp. A Boomer, 1992, LV, external view, $\mathrm{SMF}$ Xe 23805, $\mathrm{L}=0.75, \mathrm{~h}=0.60$, sample P11T. $\bullet \mathrm{B}-\mathrm{D}-$ Ogmoconcha $\mathrm{sp} .1$, sample P23; B - carapace, left view, SMF Xe 23806, L = 0.60, h=0.42; $\mathrm{C}-\mathrm{RV}$, external view, SMF Xe 23807, $\mathrm{L}=0.55, \mathrm{~h}=0.39$; D - carapace, dorsal view, SMF Xe 23808, $\mathrm{L}=0.58, \mathrm{~h}=0.39$. $\bullet \mathrm{E}-\mathrm{H}-$ Ogmoconcha sp. 2, sample P23; E - carapace, dorsal view, SMF Xe 23809, $\mathrm{L}=0.63, \mathrm{~h}=0.47 ; \mathrm{F}$ - carapace, right view, $\mathrm{SMF}$ Xe 23810, $\mathrm{L}=0.60, \mathrm{~h}=0.46 ; \mathrm{G}-\mathrm{RV}$, external view, SMF Xe 23811, L = 0.60, h = 0.43; H - LV, external view, SMF Xe 23812, L = 0.64, h = 0.48. • I-K - Ogmoconcha sp. 3; I- carapace, left view, SMF Xe 23813, L = 0.63, h =0.46, sample P4; J - carapace, right view, SMF Xe 23814, L = 0.64, h =0.47, sample P4; K - juvenile (?A-2) carapace, dorsal view, SMF Xe 23815, $\mathrm{L}=0.53, \mathrm{~h}=0.40$, sample P6. $\bullet \mathrm{L}-\mathrm{N}-$ Ogmoconchella cf. O. conversa Malz, 1971; L - carapace, right view, SMF Xe 23816, L = 0.56, h = 0.37, sample P6; M - LV, external view, SMF Xe 23817, L = 0.55, h =0.33, sample P13T; N - RV, external view, SMF Xe 23818; L = 0.58, h = 0.34, sample P13T. $\bullet-\mathrm{O}-$ Ogmoconchella cf. O. propinqua Malz, 1971, sample P6; O - carapace, dorsal view, SMF Xe $23819, \mathrm{~L}=0.63, \mathrm{~h}=0.43 ; \mathrm{P}-\mathrm{RV}$, external view, SMF Xe 23820, $\mathrm{L}=0.67, \mathrm{~h}=0.44 ; \mathrm{Q}-$ carapace, right view, $\mathrm{SMF} \mathrm{Xe} 23821, \mathrm{~L}=0.66, \mathrm{~h}=0.45$; $\mathrm{R}$ - carapace, left view, $\mathrm{SMF} X \mathrm{Xe} 23822, \mathrm{~L}=0.67, \mathrm{~h}=0.47$. Dimensions in $\mathrm{mm}$. Scale bars $=100 \mu \mathrm{m}$ 


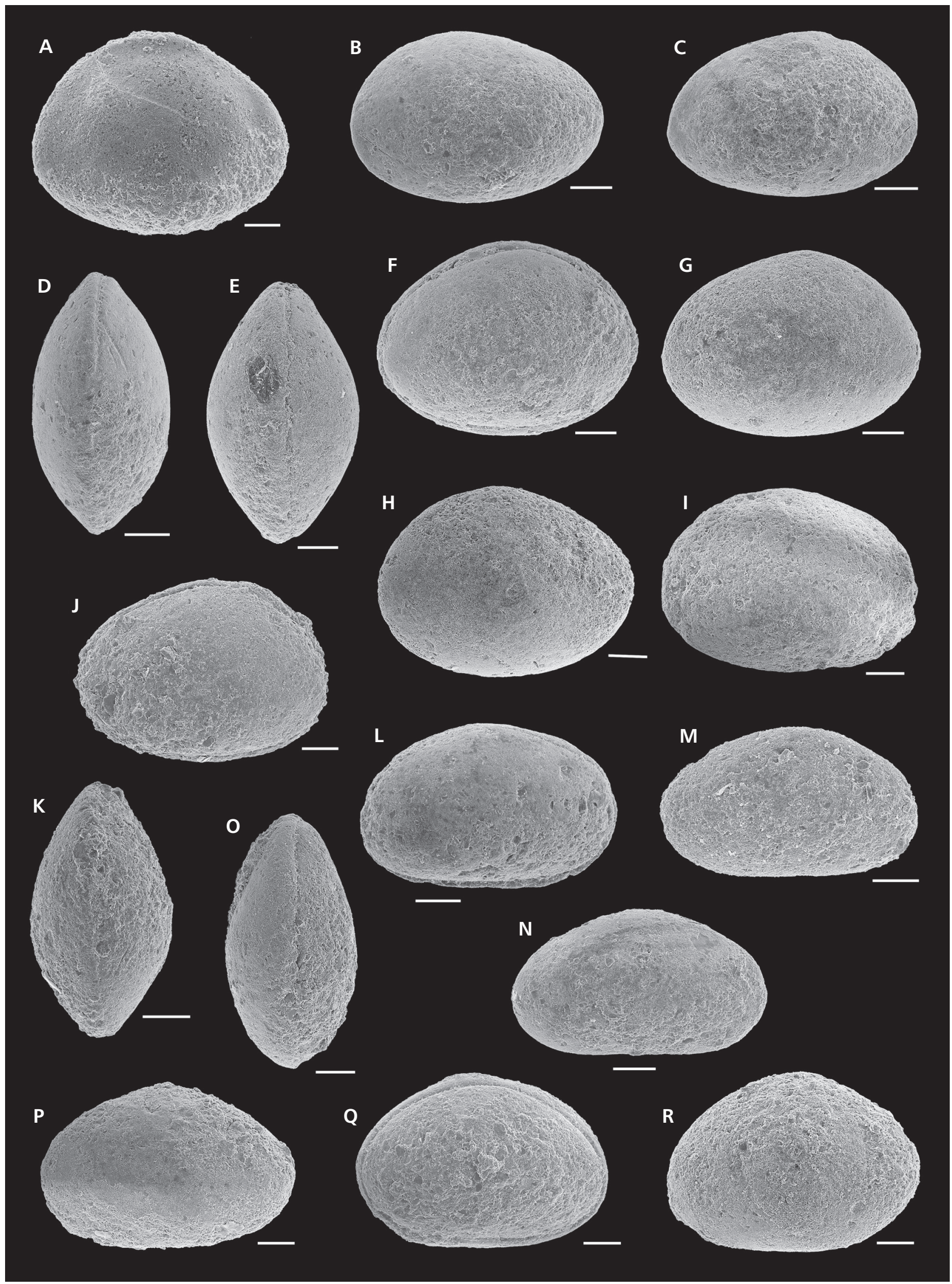


Occurrence. - Pliensbachian, emaciatum Biozone; Toarcian, polymorphum Biozone.

\section{Ogmoconcha sp. 3}

Figure 5I-K

Material. - 10 adult and juvenile C.

Remarks. - In lateral shape $O$. sp. 3 falls between $O$. sp. 1 and $O$. sp. 2 as it is more rounded posteriorly, and in dorsal view position of greatest width is relatively more towards the posterior part compared to the other two species.

Occurrence. - Pliensbachian, emaciatum Biozone; Toarcian, polymorphum Biozone.

\section{Genus Ogmoconchella Gründel, 1964}

Type species. - Healdia aspinata Drexler, 1958.

Remarks. - Following the original description of Ogmoconchella by Gründel (1964), the definition of the genus was refined by Malz (1971) as: position of greatest valve height at or posterior of mid-length, relatively weakly excavated LV contact groove and relatively simple cluster of adductor muscle scars, as compared to Ogmoconcha with position of greatest height anterior of mid-length, strongly excavated LV contact groove especially along the dorsal margin, and adductor muscle scars composed of large angular scars within a ring of small rounded scars. In some species, e.g. Ogmoconchella aspinata (Drexler, 1958) [Rhaetian-mid Sinemurian], the position of greatest height is located very posteriorly. In the Peniche material we recognized two species based on position of greatest valve height.

\section{Ogmoconchella cf. O. conversa Malz, 1971}

Figure 5L-N

cf. 1971 Ogmoconchella conversa sp. nov.; Malz, p. 443, pl. 5, fig. $27 \mathrm{a}-$ d.

Material. - Ca. 40 specimens, mostly adult V.

Remarks. - Greatest height at mid-length, appears symmetrical around mid-length in lateral view but differs in length/height ratio to Ogmoconchella propinqua which is relatively higher and more triangular in lateral view. Not common but present in 8 samples. Ogmoconchella conversa was described from the Upper Pliensbachian (margaritatus Biozone) of NW Germany.

Occurrence. - Pliensbachian, emaciatum Biozone; Toarcian, polymorphum Biozone.
Ogmoconchella cf. O. propinqua Malz, 1971

Figure 5O-R

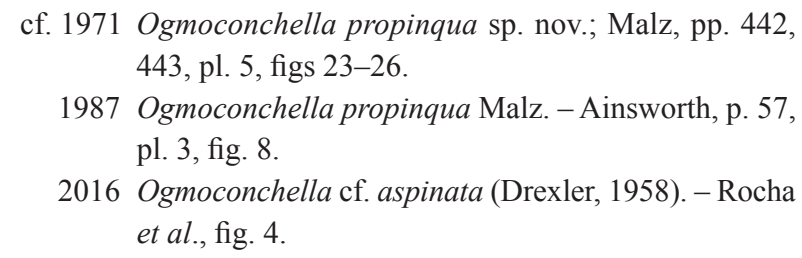

Material. - Ca. 60 specimens, mostly adult V.

Description. - Greatest height posterior of mid-length, appears asymmetrical in lateral view with antero-dorsal margin inclined anteriorly. Internal features not seen.

Remarks. - Our specimens do not preserve the fine anastomosing ribs figured by Malz (1971, pl. 5, fig. 26) in the material from the Upper Pliensbachian (margaritatus Biozone) of NW Germany. This species has been compared with Ogmoconchella aspinata from the Hettangian, and while there are some morphological similarities, including its dimensions, which are smaller than in $O$. propinqua (cf. Malz 1971), it is very unlikely that they are biologically the same species as they are separated in time by $12-13$ Ma. Ainsworth's (1987) figured specimen from the Upper Pliensbachian of the Fastnet Basin appears identical to our material.

Occurrence. - Pliensbachian, emaciatum Biozone; Toarcian, polymorphum Biozone.

Suborder Bairdiocopina Gründel, 1967

Superfamily Bairdioidea Sars, 1887

Family Bairdiidae Sars, 1887

\section{Genus Bairdia M'Coy, 1844}

Type species. - Bairdia curta M'Coy, 1844.

Remarks. - Numerous fossil species have been assigned to the genus Bairdia s. $l$. based on small differences in shape. In the present case we believe that, by comparison with other Early Jurassic species and their ranges, description of a new species is a valid and useful addition to ostracod biodiversity.

The species Bairdia molesta Apostolescu, 1959 described from the Lower Sinemurian to Upper Pliensbachian of the Paris Basin has been frequently cited in the literature, often as cf. and aff., most records of which in our opinion are not conspecific with molesta, and even the very thorough study of the species by Herrig (1979) shows LV that clearly differ in lateral outline from the figured holotype. 
Bairdia aff. B. molesta Apostolescu, 1959

Figure 6A-D

aff. 1959 Bairdia molesta n. sp.; Apostolescu, p. 806, pl. 2, fig. 31.

Material. - Ca. 90 specimens, mostly juvenile C (70).

Remarks. - The original diagnosis (translated): "Species characterized by the general outline of its carapace and by a sulcus along the anterior margin and part of the posterior margin. Valve surface smooth." (Apostolescu 1959, p. 806). The "sulcus" is interpreted by us as depressed marginal rims. In our material the depression beside the marginal rims is not so marked and the posterior margin not so acuminate as in Apostolescu's figure (1959, pl. 2, fig. 31). The species is present in the polymorphum Biozone before the CIE and then reappears as a "Lazarus" species higher in the levisoni Biozone.

Occurrence. - Pliensbachian, emaciatum Biozone; Toarcian, polymorphum and levisoni biozones.

\section{Bairdia aff. B. molesta Apostolescu, 1959 sensu Ainsworth (1987)}

Figure $6 \mathrm{E}-\mathrm{G}$

1987 Bairdia aff. molesta Apostolescu, 1959. - Ainsworth, p. 51 , pl. 1, figs $4,5,8$.

Material. -4 adult C, 1 juvenile $\mathrm{C}$.

Remarks. - The material from Peniche is identical to Bairdia aff. molesta as figured by Ainsworth (1987) from the Pliensbachian of the Fastnet Basin.

Occurrence. - Toarcian, bifrons Biozone.

\section{Bairdia paramolesta sp. nov. Cabral, Lord \& Pinto} Figure $6 \mathrm{H}-\mathrm{M}$

2007 Bairdia aff. molesta Apostolescu, 1959. - Pinto et al., pl. 1, fig. 1.

2016 Bairdia sp. 2. - Rocha et al., figs 4, 8.13.

Types. - Holotype: one adult carapace, SMF Xe 23830, $\mathrm{L}=0.80, \mathrm{~h}=0.45$, sample P11B (Fig. 6I).

Paratypes: one adult carapace, SMF Xe 23831, L = $0.80, \mathrm{~h}=0.46$, sample $\mathrm{P} 3 \mathrm{~T}$; one adult carapace, SMF Xe 23832, $\mathrm{L}=0.79, \mathrm{~h}=0.44$, sample P3T; one juvenile carapace, SMF Xe 23833, L $=0.54, \mathrm{~h}=0.30$, sample P11B; one juvenile carapace, SMF Xe 23834, L $=0.53$, $\mathrm{h}=0.31$, sample P11B.

Type horizon and locality. - Type-level sample P11B,
Toarcian, polymorphum Biozone; Praia do Abalo, Peniche, Portugal.

Material. -5 adult $\mathrm{C}, 1$ adult $\mathrm{V}, 28$ juvenile $\mathrm{C}$. The species is also present at Rabaçal, polymorphum Biozone, in sample R10, with $9 \mathrm{C}$, from which 1 adult.

Etymology. - Para Greek "close" "beside", an allusion to the morphological similarity to Bairdia molesta Apostolescu.

Diagnosis. - A species of the genus Bairdia characterized by a "bairdiid" lateral outline modified by a broadly rounded anterior margin with a marginal rim and weakly developed anterior cardinal angle.

Description. - In lateral view the typical "bairdiid" outline is modified by a very broadly rounded anterior margin running from a weakly developed anterior cardinal angle to the ventral margin. Dorsal margin gently curved. Ventral margin almost straight in LV, weakly concave in RV. Posterior margin acuminate, located ventrally. LV > RV. Position of greatest height at mid valve length, of greatest length just below mid-height and greatest width in dorsal view at mid-length. An anterior marginal rim is present and extends into the anterior part of the ventral margin, and the posterior margin also appears as a marginal rim when viewed both laterally and dorsally and extends into the posterior part of the ventral margin. Surface unornamented. Juveniles from different ontogenic stages with exactly the same characteristics of the adults, particularly the outline. The only valve is infilled with sediment and no internal details could be observed.

Dimensions: + $\mathrm{L}=0.77-0.80, \mathrm{~h}=0.44-0.46$.

Remarks. - Bairdia molesta Apostolescu described from the Sinemurian-Pliensbachian of the Paris Basin is widely recorded from the Lower Jurassic (see above). Our material from the Pliensbachian-Lower Toarcian differs from B. molesta and other described Early and Middle Jurassic age Bairdia in the broadly rounded anterior outline in lateral view.

Occurrence. - At present known only from the topmost Pliensbachian, emaciatum Biozone, at Peniche and lowest Toarcian, polymorphum Biozone, at Peniche and Rabaçal, Portugal.

\section{Bairdia cf. B. rostrata Issler, 1908}

Figure $6 \mathrm{~N}$

cf. 1908 Bairdia rostrata sp. nov.; Issler, p. 95, pl. 7, fig. 345.

2007 Bairdia aff. rostrata. - Pinto et al., pl. 1, fig. 2.

2016 Bairdia aff. rostrata. - Rocha et al., figs 4, 8.10. 
Material. - 1 adult C.

Remarks. - Bairdia rostrata was described from the Lias $\delta$ (Upper Pliensbachian) of SW Germany. Our material differs in a less rounded dorsal margin and in the higher and shorter posterior margin.

Occurrence. - Toarcian, polymorphum Biozone.

\section{Bairdia sp. 1}

Figure 6O-R

2007 Bairdia sp. 1; Pinto et al., pl. 1, figs 3, 4.

2016 Bairdia cf. kempfi Ainsworth, 1989. - Rocha et al., figs 4, 8.3.

Material. - Ca. 25 specimens, adults and juveniles, $\mathrm{V}$ and $\mathrm{C}$.

Remarks. - A species subtrapezoidal to round in lateral view with high height/length ratio, a very low short posterior margin, and in dorsal view very rounded and strongly inflated. Right valve similar to B. kempfi from the Upper Pliensbachian of the Fastnet Basin but LV more rounded and overlaps RV more strongly, and more rounded in dorsal view. Resembles B. donzei Herrig, 1979 from the Upper Pliensbachian of E Germany but differs in shape of dorsal and posterior margins.

Occurrence. - Pliensbachian, emaciatum Biozone; Toarcian, polymorphum Biozone.

\section{Bairdia sp. 2}

Figure 6S-U

Material. -3 adult C, 2 juvenile $\mathrm{C}$.

Remarks. - An elongate trapezoidal species with posterior margin just below mid-height, in dorsal view very slim and elongate. The species is characterized by the very narrow and extended carapace in dorsal view, which differs from other described non-Palaeozoic Bairdia species.

Occurrence. - Toarcian, bifrons Biozone.

\section{Genus Bairdiacypris Bradfield, 1935}

Type species. - Bairdiacypris deloi Bradfield, 1935.

Remarks. - We recognize in Peniche the species B. rectangularis Ainsworth, 1986 (Fig. 7A-C) and Bairdiacypris cf. B. triangularis Ainsworth, 1986 (Fig. 7D-F), both ori-ginally described from the ToarcianAalenian of the Fastnet Basin, but in addition we have a third form Bairdiacypris sp. 1 (Fig. 7G-I), less abundant (ca. 80 adult and juvenile C), which has a slightly convex dorsal margin inclined towards the posterior and position of greatest length at mid valve height. Our material of Bairdiacypris $\mathrm{cf}$. B. triangularis resembles the figure of Boomer \& Ainsworth (2009, pl. 1, fig. 3) from the Mochras Farm Borehole, Wales, rather than the type material from the Fastnet Basin which has a more triangular lateral outline. All three species appear in the levisoni Biozone, after the CIE, frequently together in the same sample, and $B$. rectangularis (ca. 450 adult and juvenile C) and Bairdiacypris cf. B. triangularis (ca. 180 adult and juvenile $C$ ) are abundant and dominant in the bifrons Biozone.

\section{Genus Isobythocypris Apostolescu, 1959}

Type species. - Bairdia elongata Blake, 1876.

Remarks. - Several poorly preserved and crushed unornamented specimens (ca. $25 \mathrm{C}$ and $\mathrm{V}$ ) may belong to Isobythocypris. We figure material that resembles I. ovalis Bate \& Coleman, 1975 (Fig. 7J, K) from the Lower Toarcian of England.

Figure 6. Toarcian ostracods from Peniche section, Portugal. - A-D - Bairdia aff. B. molesta Apostolescu, 1959, polymorphum Biozone; A - carapace, right view, SMF Xe 23823, L = 0.67, h =0.40, sample P11B; B - carapace, left view, SMF Xe 23824, L = 0.68, h=0.40, sample P11B; $\mathrm{C}$ - juvenile (?A-2) carapace, left view, SMF Xe 23825, $\mathrm{L}=0.44, \mathrm{~h}=0.28$, sample P23; D - carapace, dorsal view, $\mathrm{SMF} \mathrm{Xe} 23826, \mathrm{~L}=0.65, \mathrm{~h}=0.36$, sample P13B. • E-G - Bairdia aff. B. molesta Apostolescu, 1959 sensu Ainsworth (1987), bifrons Biozone; E - carapace, dorsal view, SMF Xe 23827, $\mathrm{L}=0.33, \mathrm{~h}=0.21$, sample P404; F - carapace, right view, SMF Xe 23828, L = 0.36, h =0.23, sample P404; G - carapace, left view, SMF Xe 23829, $\mathrm{L}=0.35, \mathrm{~h}=0.23$, sample $\mathrm{P} 406 . \cdot \mathrm{H}-\mathrm{M}-$ Bairdia paramolesta sp. nov. Cabral, Lord \& Pinto, polymorphum Biozone; $\mathrm{H}$ - carapace, dorsal view, paratype, SMF Xe 23831, L =0.80, h =0.46, sample P3T; I - carapace, right view, holotype, SMF Xe 23830, L = 0.80, h $=0.45$, sample P11B; J - carapace, left view, paratype, SMF Xe 23832, L =0.79, $\mathrm{h}=0.44$, sample P3T; $\mathrm{K}$ - juvenile (?A-2) carapace, dorsal view, paratype, $\mathrm{SMF} X \mathrm{Xe} 23833, \mathrm{~L}=0.54, \mathrm{~h}=0.30$, sample P11B; L - juvenile (?A-2) carapace, left view, paratype, SMF Xe 23834, L =0.53, h =0.31, sample P11B; M - juvenile (?A-2) carapace, right view, same specimen as L. $\bullet \mathrm{N}-$ Bairdia $\mathrm{cf}$. B. rostrata Issler, 1908, carapace, left view, SMF Xe 23835, L $=0.61, \mathrm{~h}=0.37$, polymorphum Biozone, sample P4. - O-R - Bairdia sp. 1, polymorphum Biozone, sample P4; O - RV, external view, SMF Xe 23836, L = 0.67, h $=0.45 ; \mathrm{P}-\mathrm{LV}$, external view, SMF Xe 23837, L = 0.67, h = 0.50; Q - carapace, right view, SMF Xe 23838, L =0.69, h =0. 50; $\mathrm{R}$ - carapace, dorsal view, same specimen as Q. S-U - Bairdia sp. 2, bifrons Biozone; S - carapace, dorsal view, SMF Xe 23839, L $=0.68, \mathrm{~h}=0.36$, sample P412; $\mathrm{T}$ - carapace, right view, SMF Xe 23840, $\mathrm{L}=0.68, \mathrm{~h}=0.35$, sample P401; $\mathrm{U}$ - carapace, left view, SMF Xe 23841, $\mathrm{L}=0.67, \mathrm{~h}=0.36$, sample P406. Dimensions in mm. Scale bars $=100 \mu \mathrm{m}$. 


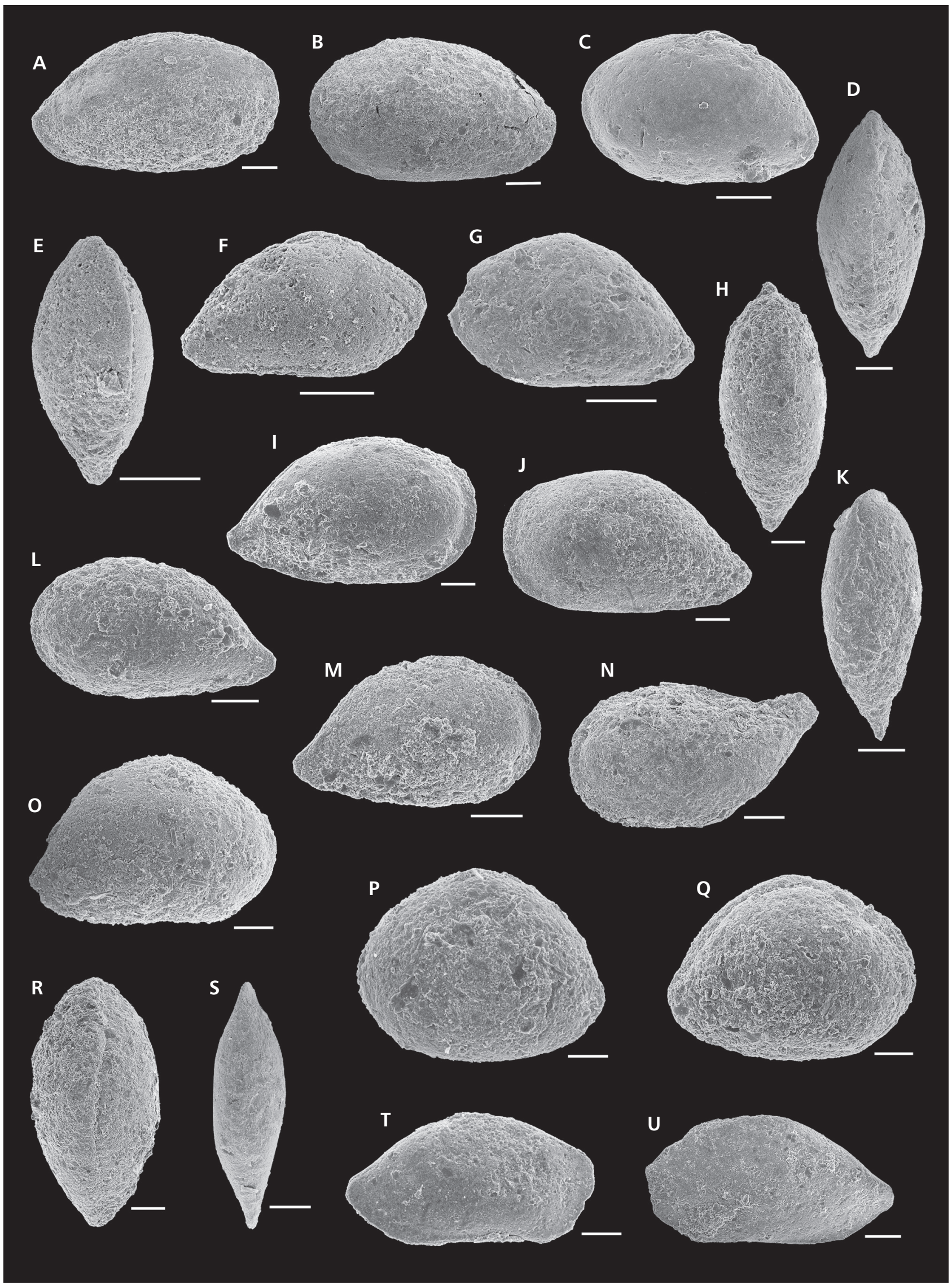


Genus Ptychobairdia Kollmann, 1960

Type species. - Ptychobairdia kuepperi Kollmann, 1960.

\section{Ptychobairdia hahni (Lord \& Moorley, 1974)}

Figure 7L-N

1974 Bairdia hahni sp. nov.; Lord \& Moorley, pp. 1-4, pl. 2:1:2, 2:1:4.

1979 Bairdia sp. 2. - Exton, p. 54, pl. 9, fig. 2.

2007 Ptychobairdia hahni (Lord \& Moorley). - Pinto et al., pl. 2, fig. 20.

2007 Ptychobairdia cf. hahni (Lord \& Moorley). - Pinto et al., pl. 2, fig. 8 .

2016 Ptychobairdia hahni (Lord \& Moorley). - Rocha et al., figs 4, 8.8.

Material. - Ca. 80 specimens, all C, adult (32) and juveniles.

Remarks. - The species hahni, originally described from the Upper Pliensbachian of SW Germany, is common in Peniche until the levisoni biozone, though generally very worn. The species has a very distinctive lateral outline, and there is some variation in size (adults and juveniles?) and in the presence and strength of surface ornamentation (preservation).

Occurrence. - Pliensbachian, emaciatum Biozone; Toarcian, polymorphum and levisoni biozones.

Suborder Cytherocopina Baird, 1850

Superfamily Cytheroidea Baird, 1850

Family Bythocytheridae Sars, 1926

\section{Genus Patellacythere Gründel \& Kozur, 1971}

Type species. - Monoceratina williamsi Stephenson, 1946.
Remarks. - Jurassic species formerly placed in Monoceratina Roth, 1928 have been revised, see discussion in Pais et al. (2016, p. 213).

\section{Patellacythere ungulina (Triebel \& Bartenstein, 1938) \\ Figure 7O, P}

1938 Monoceratina ungulina sp. nov.; Triebel \& Bartenstein, pp. 506, 508, figs 3, 4 .

1999a Monoceratina ungulina Triebel \& Bartenstein. - Arias \& Lord, p. 92, pl. 4, fig. 6.

Material. -18 adult C, 16 juvenile C.

Remarks. - Patellacythere ungulina, described originally from the Lias $\zeta$ (Upper Toarcian) of SW Germany, occurs commonly but not abundantly in Peniche, poorly preserved.

Occurrence. - Toarcian, bifrons Biozone.

Genus Praebythoceratina Gründel \& Kozur, 1972

Type species. - Bythoceratina progacilis Kozur, 1972.

\section{?Praebythoceratina sp. 1}

Figure 7Q, R

2007 Cytheropteron aff. alafastigatum Fischer, 1962. - Pinto et al., pl. 2, figs 12, 13.

Material. -4 adult C.

Remarks. - The rare specimens show a lateral spine on each valve, a weak sulcus and appear to have straight dorsal margins, indicating the genus Praebythoceratina.

Figure 7. Toarcian ostracods from Peniche section, Portugal. • A-C - Bairdiacypris rectangularis Ainsworth, 1986, bifrons Biozone, sample P422; $\mathrm{A}$ - carapace, right view, SMF Xe 23842, $\mathrm{L}=0.48, \mathrm{~h}=0.25$; B - carapace, left view, SMF Xe 23843, $\mathrm{L}=0.44, \mathrm{~h}=0.24$; $\mathrm{C}-$ carapace, dorsal view, SMF Xe 23844, $\mathrm{L}=0.49, \mathrm{~h}=0.26 . \cdot \mathrm{D}-\mathrm{F}-$ Bairdiacypris $\mathrm{cf}$. B. triangularis Ainsworth, 1986, bifrons Biozone, sample P422; D - carapace, dorsal view, SMF Xe 23845, L = 0.51, h =0.28; E - carapace, right view, SMF Xe 23846, L = 0.45, h =0.25; F - carapace, left view, SMF Xe 23847, $\mathrm{L}=0.49, \mathrm{~h}=0.26 . \cdot \mathrm{G}-\mathrm{I}-$ Bairdiacypris sp. 1, levisoni Biozone; sample P142; G - carapace, right view, SMF Xe $23848, \mathrm{~L}=0.49, \mathrm{~h}=0.25$; $\mathrm{H}$ - carapace, left view, SMF Xe 23849, $\mathrm{L}=0.47, \mathrm{~h}=0.25 ; \mathrm{I}$ - carapace, dorsal view, SMF Xe $23850, \mathrm{~L}=0.47, \mathrm{~h}=0.24$. $・ \mathrm{~J}, \mathrm{~K}-$ Isobythocypris aff. I. ovalis Bate \& Coleman, 1975, polymorphum Biozone, sample P25; J - carapace, dorsal view, SMF Xe 23851, L $=0.47, \mathrm{~h}=0.26$; K - carapace, right view, SMF Xe 23852, $\mathrm{L}=0.52, \mathrm{~h}=0.29 . \cdot \mathrm{L}-\mathrm{N}-$ Ptychobairdia hahni (Lord \& Moorley, 1974), polymorphum and levisoni biozones; $\mathrm{L}$ - juvenile (?A-2) carapace, left view, SMF Xe 23853, $\mathrm{L}=0.44, \mathrm{~h}=0.25$, levisoni Biozone, sample P41; M - carapace, left view, SMF Xe 23854, $\mathrm{L}=0.60, \mathrm{~h}=0.29$, polymorphum Biozone, sample P6; $\mathrm{N}$ - carapace, right view, SMF Xe 23855, $\mathrm{L}=0.60, \mathrm{~h}=0.30$, polymorphum Biozone, sample P6. O, P - Patellacythere ungulina (Triebel \& Bartenstein, 1938), bifrons Biozone; O - juvenile (?A-1) carapace, left view, SMF Xe 23856, L = 0.47, $\mathrm{h}=0.24$, sample P392; P - carapace, right view, SMF Xe 23857, $\mathrm{L}=0.55, \mathrm{~h}=0.30$, sample P401. $\bullet \mathrm{Q}, \mathrm{R}-$ ?Praebythoceratina sp. 1, levisoni and bifrons biozones; Q - carapace, left view, SMF Xe 23858, $\mathrm{L}=0.45, \mathrm{~h}=0.26$, bifrons Biozone, sample P396; $\mathrm{R}$ - carapace, dorsal view, SMF Xe 23859, $\mathrm{L}=0.54, \mathrm{~h}=0.29$, levisoni Biozone, sample P56. $-\mathrm{S}-\mathrm{U}-$ ?"Monoceratina” sp. 1 Cabral et al., 2015, bifrons Biozone, sample $\mathrm{P} 422 ; \mathrm{S}-\mathrm{carapace}$, dorsal view, $\mathrm{SMF} X \mathrm{Xe} 23860, \mathrm{~L}=0.37, \mathrm{~h}=023 ; \mathrm{T}$ - carapace, left view, SMF Xe 23861, $\mathrm{L}=0.36, \mathrm{~h}=0.23 ; \mathrm{U}-$ carapace, right view, SMF Xe 23862, $\mathrm{L}=0.36, \mathrm{~h}=0.23 . \bullet \mathrm{V}-$ Tanycythere sp., carapace, left view, SMF Xe 23863, L $=0.53, \mathrm{~h}=0.21$, bifrons Biozone, sample P396. $\bullet \mathrm{W}-$ Cytheropteron cf. C. alafastigatum Fischer, 1962, left valve, external view, SMF Xe 23864, L =0.51, h = 0.32 (including wing), bifrons Biozone, sample P406. Dimensions in $\mathrm{mm}$. Scale bars $=100 \mu \mathrm{m}$. 


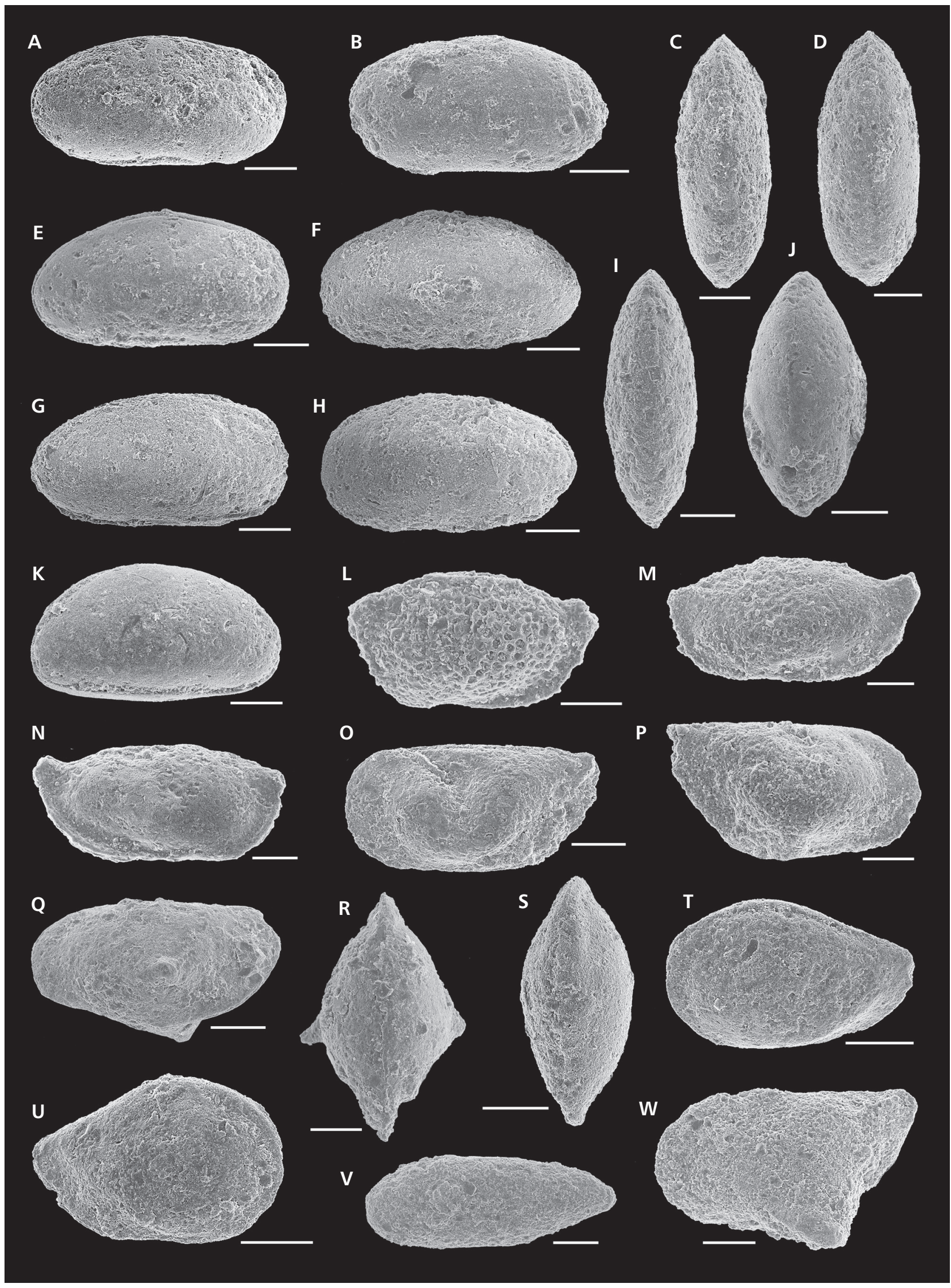


Occurrence. - Toarcian, levisoni and bifrons biozones.

Genus Tanycythere Cabral, Lord, Boomer \& Malz, 2014

Type species. - Tanycythere caudata Cabral, Lord, Boomer \& Malz, 2014.

Remarks. - Tanycythere occurs rarely (2 C) in the bifrons Biozone (Fig. 7V). The rare specimens seem different from all the species described in Cabral et al. (2014).

\section{?"Monoceratina" sp. 1 Cabral et al., 2015}

Figure $7 \mathrm{~S}-\mathrm{U}$

1999a Monoceratina sp. A; Arias \& Lord, p. 94, pl. 4, fig. 7.

2015 “Monoceratina"? sp. 1; Cabral et al., p. 6, pl. 1, figs $1-3$.

Material. -16 adult C.

Remarks. - Evgenij I. Shornikov (personal communication 2013) advised that this species, although relatively close to the genus Monoceratina Roth, represents a new genus of the Bythocytheridae. The species is recorded from the Sinemurian of western Portugal and from the Toarcian (tenuicostatum and bifrons biozones) of Cordillera Iberica (Iberian Range), NE Spain, occurs rarely in Peniche. A similar form is known in the Lower Jurassic of the Mochras Farm Borehole, Wales (Boomer, personal communication 2014) of Great Britain.

Occurrence. - Toarcian, levisoni and bifrons biozones.

Family Cytheruridae G.W. Müller, 1894

\section{Genus Cytheropteron Sars, 1866}

Type species. - Cythere latissima Norman, 1865.

\section{Cytheropteron cf. C. alafastigatum Fischer, 1962}

Figure 7W

cf. 1962 Cytheropteron alafastigatum sp. nov.; Fischer, pp. 336-338, pl. 20, figs 1-6.

Material. - 3 adult V, 1 juvenile V.

Remarks. - Originally described from the Upper Toarcian of SW Germany; occurs rarely in Peniche; ventral winglike extension less well developed than in original material possibly due to preservational reasons.

Occurrence. - Toarcian, bifrons Biozone.

Family Protocytheridae Ljubimova, 1955

\section{Genus Ektyphocythere Bate, 1963}

Type species. - Procytheridea triangula Brand in Brand \& Malz, 1961.

Remarks. - The genus Ektyphocythere is present in several levels of the Peniche section, particularly in the polymorphum and levisoni biozones, sometimes well represented; however, most specimens are too poorly preserved to be identified to species level. We identified five species.

\section{Ektyphocythere cf. E. bucki (Bizon, 1960) Figure 8A, B}

cf. 1960 Procytheridea bucki n. sp.; Bizon, p. 205, pl. 1, fig. 2a-e. 1979 Ektyphocythere sp. 1. - Exton, p. 58, pl. 13, figs 3-5. cf. 1999b Ektyphocythere bucki (Bizon). - Arias \& Lord, p. 228, pl. 3, fig. 1 .

Material. -2 adult $\mathrm{C}$.

Figure 8. Toarcian ostracods from Peniche section, Portugal. • A, B - Ektyphocythere cf. E. bucki (Bizon, 1960), bifrons Biozone, sample P317; $\mathrm{A}$ - carapace, dorsal view, SMF Xe 23865, L = 0.53, h =0.38; B - carapace, right view, SMF Xe 23866, L = 0.61, h $=0.40$. $\bullet$ C - Ektyphocythere cf. E. dharennsourensis Boutakiout, Donze \& Oulmach, 1982, female carapace, left view, SMF Xe 23867, L = 0.76, h=0.47, levisoni Biozone, sample P65. - D-F - Ektyphocythere intrepida (Bate \& Coleman, 1975), levisoni Biozone, sample P86; D - juvenile (?A-1) carapace, dorsal view, SMF Xe 23868, L = 0.48, h=0.27; E - LV, external view, SMF Xe 23869, L =0.65, h =0.37; F $-\mathrm{RV}$, external view, SMF Xe 23870, L =0.62, h=0.33. • G-J - Ektyphocythere knitteri (Riegraf, 1984), polymorphum Biozone; G - male carapace, right view, SMF Xe 23871, L =0.60, h = 0.29, sample P11T; $\mathrm{H}$ - female carapace, dorsal view, SMF Xe 23872, L =0.55, h = 0.30, sample P11T; I - female carapace, right view, $\mathrm{SMF} X \mathrm{Xe} 23873, \mathrm{~L}=0.54, \mathrm{~h}=0.29$, sample P13B; J - female carapace, left view, SMF Xe 23874, L =0.49, h =0.28, sample P13B. • K - Ektyphocythere cf. E. lanceolata Boomer, 1988, $\mathrm{RV}$, external view, SMF Xe 23875, L =0.60, $\mathrm{h}=0.28$, polymorphum Biozone, sample P23. • L-O Kinkelinella costata Knitter, 1983, bifrons Biozone; $\mathrm{L}-\mathrm{LV}$, external view, SMF Xe 23876, $\mathrm{L}=0.55, \mathrm{~h}=0.42$, sample P373; M - carapace, dorsal view, SMF Xe 23877, $\mathrm{L}=0.55, \mathrm{~h}=0.44, \mathrm{sample} \mathrm{P} 414$; $\mathrm{N}$ - LV, external view, SMF Xe 23878, L = 0.61, h=0.43, sample P422; O - carapace, right view, SMF Xe 23879, L=0.58, h =0.40, sample P373. • $\mathrm{P}-\mathrm{U}-$ Kinkelinella sermoisensis Apostolescu, 1959, levisoni and bifrons biozones; $\mathrm{P}-\mathrm{LV}$, external view, SMF Xe 23880, L = 0.55, h $=0.32$, levisoni Biozone, sample P28; Q - carapace, dorsal view, SMF Xe 23881, L = 0.53, h = 0.33, levisoni Biozone, sample P28; R - RV, external view, SMF Xe 23882, $\mathrm{L}=0.68, \mathrm{~h}=0.40$, bifrons Biozone, sample P422; $\mathrm{S}-\mathrm{RV}$, external view, SMF Xe 23883, L =0.63, h=0.41, bifrons Biozone, sample P317; $\mathrm{T}$ - carapace, dorsal view, $\mathrm{SMF}$ Xe 23884, $\mathrm{L}=0.65, \mathrm{~h}=0.45$, bifrons Biozone, sample P317; U $-\mathrm{LV}$, external view, $\mathrm{SMF}$ Xe 23885, $\mathrm{L}=0.65, \mathrm{~h}=0.45$, bifrons Biozone, sample P317. Dimensions in $\mathrm{mm}$. Scale bars $=100 \mu \mathrm{m}$. 


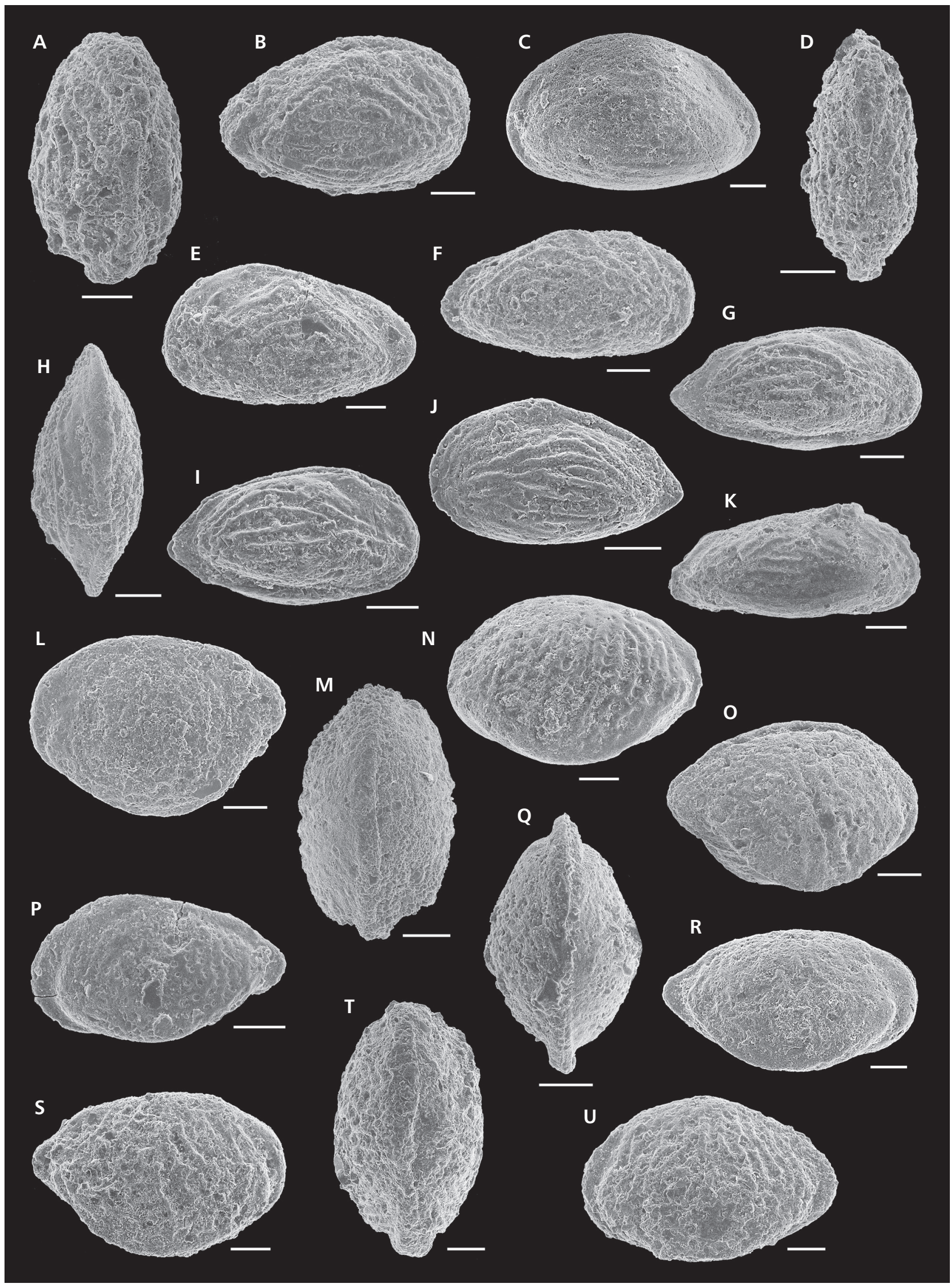


Remarks. - Originally described from the Middle-Upper Toarcian of the Paris Basin, also occurs in the Toarcian at Rabaçal and in NE Spain; it is rare in Peniche.

Occurrence. - Toarcian, bifrons Biozone.

Ektyphocythere cf. E. dharennsourensis Boutakiout, Donze \& Oulmach, 1982

Figure 8C

cf. 1982 Ektyphocythere dharennsourensis n. sp.; Boutakiout, Donze \& Oulmach, p. 97, pl. 1, figs 9, 10, 11a-c, 12a, b.

1992 Ektyphocythere dharennsourensis Boutakiout, Donze \& Oulmach. - Boomer, p. 54, pl. 2, figs 4-6, 8, 9, 11.

1999b Ektyphocythere cf. dharennsourensis Boutakiout, Donze \& Oulmach. - Arias \& Lord, p. 229, pl. 3, fig. 2.

2007 Ektyphocythere aff. debilis (Bate \& Coleman, 1995). - Pinto et al., pl. 2, figs 14, 15.

Material. - Ca. 60 adult and juvenile V.

Remarks. - Originally described from the Lower-Middle Toarcian of Morocco but also recorded from NE Spain (Arias \& Lord 1999b) and southern Great Britain (Boomer 1992), occurs in Peniche only in the levisoni Biozone in the CIE; it is characterized by a weak ornamentation and a sub-quadrate to sub-triangular lateral view.

Occurrence. - Toarcian, levisoni Biozone.

Ektyphocythere intrepida (Bate \& Coleman, 1975) Figure 8D-F

1975 Kinkelinella (Ektyphocythere) intrepida sp. nov.; Bate \& Coleman, pp. 20, 21, pl. 7, figs 1-5, 8-10, pl. 8, figs 7, 8, figs 10a, 11c.

2007 Ektyphocythere aff. intrepida (Bate \& Coleman). Pinto et al., pl. 2, figs 16, 17.

Material. -4 adult C, 7 adult V.

Remarks. - Originally described from the Lower Toarcian of Great Britain, is rarely represented at Peniche in levisoni and bifrons biozones; easily identified by its ornamentation with the apex of the typical triangle projecting above the dorsal outline in the RV.

Occurrence. - Toarcian, levisoni and bifrons biozones.

\section{Ektyphocythere knitteri (Riegraf, 1984)}

Figure $8 \mathrm{G}-\mathrm{J}$

1984 Kinkelinella (Ektyphocythere) knitteri sp. nov.; Riegraf, p. 5, pl. 1, figs 4-6.
2007 Ektyphocythere cf. knitteri (Riegraf). - Pinto et al., pl. 1, figs 9-11.

2016 Ektyphocythere knitteri (Riegraf). - Rocha et al., figs $4,8.12$.

Material. - Ca. 40 specimens, mostly adults, C and V.

Remarks. - Originally described from the Lower Toarcian of SW Germany, is an important species in the polymorphum Biozone at Peniche, still rarely appearing in the extreme base of the levisoni Biozone; the Portuguese specimens are similar to the German ones.

Occurrence. - Toarcian, polymorphum and levisoni biozones.

\section{Ektyphocythere cf. E. lanceolata Boomer, 1988 \\ Figure 8K}

cf. 1988 Ektyphocythere lanceolata sp. nov.; Boomer, pp. 89-92.

Material. - 1 ?adult RV.

Remarks. - A single specimen found at Peniche, with a particularly elongate lateral outline, tapering posteriorly, and the ornamentation with longitudinal ribs and fine intercostal punctation, seems relatively close to E. lanceolata, originally described from the Upper Toarcian of Mochras Farm Borehole, Great Britain.

Occurrence. - Toarcian, polymorphum Biozone.

\section{Genus Kinkelinella Martin, 1960}

Type species. - Kinkelinella tenuicostati Martin, 1960.

Remarks. - Kinkelinella appeared in the earliest Toarcian, having evolved apparently from the related genus Ektyphocythere Bate, 1963, and ranges to the Bathonian (Bate 2009 , p. 219). Opinion differs as to the systematic relationship of the two genera with some authors considering Ektyphocythere a subgenus of Kinkelinella (e.g. Bate \& Coleman 1975, Bate 2009), although we follow Ainsworth \& Boomer (2009) in regarding them as distinct genera. At least 20 species are described.

\section{Kinkelinella costata Knitter, 1983}

Figure 8L-O

1983 Kinkelinella (Kinkelinella) costata sp. nov.; Knitter, p. 224, pl. 39, figs 7-10.

1979 Kinkelinella sp. I (Apostolescu). - Exton, p. 60, pl. 13, figs 6-12. 
Material. - Ca. 60 adults, mostly V and 45 juvenile V.

Remarks. - Kinkelinella costata, originally described from the Toarcian of SW Germany, also occurs in the Toarcian at Rabaçal and at Boca da Mata. The surface ornament of $K$. costata is characterized by strong vertical ribs and a ventral alar wing both slightly varying in thickness and extension.

Occurrence. - Toarcian, bifrons Biozone.

\section{Kinkelinella sermoisensis (Apostolescu, 1959)} Figure 8P-U

1959 Procytheridea sermoisensis n. sp.; Apostolescu, p. 812, pl. 3, figs 37, 38 .

1979 Kinkelinella sermoisensis (Apostolescu). - Exton, p. 59, pl. 12, figs 1-4.

1984 Kinkelinella sermoisensis (Apostolescu). - Exton \& Gradstein, pl. 2, fig. 8.

1999b Kinkelinella sermoisensis (Apostolescu). - Arias \& Lord, pp. 232, 233, pl. 3, fig. 6.

Material. - Ca. 120 specimens, mostly V, adults (68) and juveniles (45).

Remarks. - Kinkelinella sermoisensis occurs in the Toarcian at Peniche, in levisoni and bifrons biozones and in the Toarcian at Rabaçal and Boca da Mata, and is characterized by reticulate surface ornament. In fact the species, originally described from the Toarcian and Aalenian of the Paris Basin, is characterized across Western Europe by variable strength ornament as demonstrated for example from the Paris Basin by Bizon (1960) and here (Fig. 8P-R and $8 \mathrm{~S}-\mathrm{U})$. The species is present in the bottom sample of the CIE and then reappears as a "survivor" species higher in the levisoni Biozone and continues commonly in the bifrons Biozone.

Occurrence. - Toarcian, levisoni and bifrons Biozone.

\section{Kinkelinella ventrocarinata sp. nov. Cabral, Pinto \& Lord}

Figure 9A-J

1979 Kinkelinella sp. - Exton, pp. 60, 61, pl. 10, figs 1-3.

2007 Kinkelinella sp. 1. - Pinto et al., pl. 1, figs 12, 13.

2016 Kinkelinella sp. 1. - Rocha et al., figs 4, 8.9.

Types. - Holotype: one female LV, SMF Xe 23886; L = $0.63, \mathrm{~h}=0.42$, sample R7T (Fig. 9A, F).

Paratypes: one female carapace, SMF Xe 23887, L = $0.64, \mathrm{~h}=0.44$, sample R10; one female carapace, SMF
Xe 23888, $\mathrm{L}=0.70, \mathrm{~h}=0.43$, sample $\mathrm{R} 10$; one female $\mathrm{RV}$, SMF Xe 23889, $\mathrm{L}=0.58, \mathrm{~h}=0.37$, sample R7T; one male RV, SMF Xe 23890, $\mathrm{L}=0.63, \mathrm{~h}=0.35$, sample R7T.

Diagnosis. - A species of Kinkelinella distinguished by an inflated ornamented carapace with a swollen ventral carinate margin.

Material. - Peniche - 54 adult V, 2 adult C, 29 juvenile V, 1 juvenile $C$. Rabaçal -106 adult V, 8 adult $C, 72$ juvenile V, 2 juvenile $\mathrm{C}$.

Etymology. - A reference to the carinate ridge running roughly parallel to the ventral margin.

Type horizon and locality. - Type-level sample R7T, Toarcian, polymorphum Biozone; Rabaçal, Portugal.

Description. - Left valve triangular in lateral outline with position of greatest height just anterior of mid-length. Right valve appears more rectangular in lateral view with dorsal and ventral margins roughly parallel. LV $>$ RV. Ventral alar wing well-developed and conceals ventral margin in lateral view. Anterior margin broadly rounded at about mid-valve height, posterior margin triangular and close to ventral margin; anterior and posterior marginal rims well-developed. Surface ornament comprises a strong primary rib running along the margin of the alar wing and extending anteriorly towards the anterior cardinal angle, two weaker ribs running from the mid dorsal area and curving anteriorly, and other weaker ribs running posteroventrally from the dorsal margin; the overall impression is of a triangular pattern not uncommon in Early Jurassic cytheroid ostracods. In dorsal view greatest width is at mid-length and the marginal rims are prominent. In ventral view longitudinal grooves run from the anterior to posterior. Ocular structures are not evident externally or internally.

Valves are thick walled and heavily calcified. Internally marginal zone and line of concrescence coincide. Hingement strongly antimerodont with large terminal elements each containing 7-8 teeth in the RV and crenulated medium element; large accommodation groove in LV. Marginal and normal pore canals not known. Muscle scars not known. Sexual dimorphism evident with males relatively longer and less high than females, although in dorsal view both have greatest width at mid-length. Juveniles show weakly developed ornament.

Dimensions: Rabaçal - Q $\mathrm{L}=0.58-0.70, \mathrm{~h}=0.37-$ 0.46 ; $\hat{O} \mathrm{~L}=0.63-0.71, \mathrm{~h}=0.35-0.43$. Peniche $-9 \mathrm{~L}=$ $0.60-0.69, \mathrm{~h}=0.41-0.46 ; \hat{\mathrm{O}} \mathrm{L}=0.65-0.68, \mathrm{~h}=0.37-0.44$.

Remarks. - The species is defined and figured using 
material from the Rabaçal section which is much better preserved than material of this species from Peniche.

Kinkelinella ventrocarinata sp. nov. occurs in the lowest part of the polymorphum Biozone prior to the appearance of $K$. sermoisensis Apostolescu. K. ventrocarinata sp. nov. differs from $K$. sermoisensis in having a less well-developed alar wing structure and in surface ornament which consists of a strong latitudinal carinate rib along the wing with weaker ribs radiating from the dorsal margin to form an overall triangular pattern.

Kinkelinella costata differs from $K$. ventrocarinata sp. nov. in having stronger vertical ribs and the alar wing more ventrally extended.

Occurrence. - At present known only from the lowest Toarcian at Peniche and Rabaçal, Portugal, and from the Lower Toarcian of Robinswood Hill, Gloucestershire, UK (Lord, unpublished data).

\section{Genus unknown}

\section{Genus unknown spp.}

Figure $9 \mathrm{~K}-\mathrm{M}$

Material. - Ca. 20 specimens, mostly adults, V (13 adult) and $\mathrm{C}$.

Remarks. - A group of specimens with a relatively elongate form, punctate ornament and strong triangular posterior rim represent an unknown genus and may comprise more than one species. The general outline resembles Ektyphocythere, although not in detail, and the ornament lacks the characteristic triangular arrangement of ribs. Similarly, the lateral outline resembles some Kinkelinella species but it lacks the strongly developed ventral alar wing.

Occurrence. - Toarcian, levisoni and bifrons biozones.

Family Schulerideidae Mandelstam, 1959
Genus Praeschuleridea Bate, 1963

Type species. - Cytheridea subtrigona Jones \& Sherborn, 1888.

Praeschuleridea cf. P. pseudokinkelinella Bate \& Coleman, 1975

Figure 9N-R

cf. 1975 Praeschuleridea pseudokinkelinella sp. nov.; Bate \& Coleman, p. 24, pl. 7, figs 6, 7, 11-13, pl. 10, figs 1-7, 9-11, 13.

1986 Praeschuleridea cf. pseudokinkelinella Bate \& Coleman. - Ainsworth, p. 322, pl. 11, figs 1-8.

1999b Praeschuleridea pseudokinkelinella Bate \& Coleman. - Arias \& Lord, pp. 236, 237, pl. 4, fig. 5 .

Material. - Ca. 50 adult specimens, mostly valves (43).

Remarks. - Praeschuleridea pseudokinkelinella was originally described from the basal Toarcian of Great Britain. Our material $P$. cf. $P$. pseudokinkelinella is similar to but not identical with the well-preserved type material; material from the Toarcian-Aalenian of the Fastnet Basin figured by Ainsworth (1986) is also similar but difficult to compare for preservational reasons of both Irish and Portuguese forms although both differ posteriorly and in length:height ratio from the types. Our material shows some variation in outline and in strength of ornamentation; however, the genus Praeschuleridea is defined by its paleohemimerodont hingement which cannot be observed in our specimens which probably represent more than one species (including some Ektyphocythere).

Occurrence. - Toarcian, bifrons Biozone.

Suborder Cypridocopina Baird, 1845

Superfamily Cypridoidea Baird, 1845

Family Candonidae Kaufmann, 1900

Figure 9. Toarcian ostracods from Rabaçal (A-G) and Peniche (H-T) sections, Portugal. • A-J - Kinkelinella ventrocarinata sp. nov. Cabral, Pinto \& Lord, polymorphum Biozone; A - female LV, external view, holotype, SMF Xe 23886, L = 0.63, h = 0.42, sample R7T; B - female carapace, dorsal view, paratype, $\mathrm{SMF} X \mathrm{Xe} 23887, \mathrm{~L}=0.64, \mathrm{~h}=0.44$, sample $\mathrm{R} 10 ; \mathrm{C}-$ female carapace, ventral view, paratype, $\mathrm{SMF} \mathrm{Xe} 23888, \mathrm{~L}=0.70, \mathrm{~h}=0.43$, sample R10; D - female RV, internal view, paratype, SMF Xe 23889, L = 0.58, h = 0.37, sample R7T; E - female RV, internal view, detail of D (hinge); $\mathrm{F}$ - female LV, internal view, holotype, detail of the hinge, sample R7T; $\mathrm{G}-$ male RV, external view, paratype, SMF Xe 23890, L $=0.63$, h $=0.35$, sample R7T; H - female carapace, dorsal view, SMF Xe 23891, L =0.61, h =0.40, sample P11B; I - female LV, external view, SMF Xe 23892, $\mathrm{L}=0.62, \mathrm{~h}=0.42$, sample P3T; $\mathrm{J}$ - female carapace, right view, SMF Xe 23893, L = 0.65, h=0.41, sample P8. $\mathrm{K}-\mathrm{M}-\mathrm{Genus}$ unknown spp, bifrons Biozone; K - LV, external view, SMF Xe 23894, L =0.50, h=0.28, sample P406; L - LV, external view, SMF Xe 23895, L =0.53, h = 0.20, sample P422; M - RV, external view, SMF Xe 23896, $\mathrm{L}=0.51, \mathrm{~h}=0.25$, sample P422. $-\mathrm{N}-\mathrm{R}-$ Praeschuleridea cf. P. pseudokinkelinella Bate \& Coleman, 1975, bifrons Biozone; N - RV, external view, SMF Xe 23897, L =0.62, h =0.38, sample P373; O - LV, external view, SMF Xe 23898, L = 0.63, $\mathrm{h}=0.39$, sample P408; P - carapace, dorsal view, SMF Xe 23899, L = 0.60, h = 0.36, sample P408; Q - LV, external view, SMF Xe 23900, L = 0.59, $\mathrm{h}=0.39$, sample P406; $\mathrm{R}-\mathrm{LV}$, external view, SMF Xe 23901, L =0.68, h=0.45, sample P422. • S, T - Paracypris cf. P. redcarensis (Blake, 1876), polymorphum Biozone; $\mathrm{S}$ - carapace, dorsal view, SMF Xe 23902, L =0.45, h=0.23, sample P11B; T - carapace, right view, SMF Xe 23903, L = 0.44, $\mathrm{h}=0.23$, sample P23. Dimensions in $\mathrm{mm}$. Scale bars $=100 \mu \mathrm{m}$. 


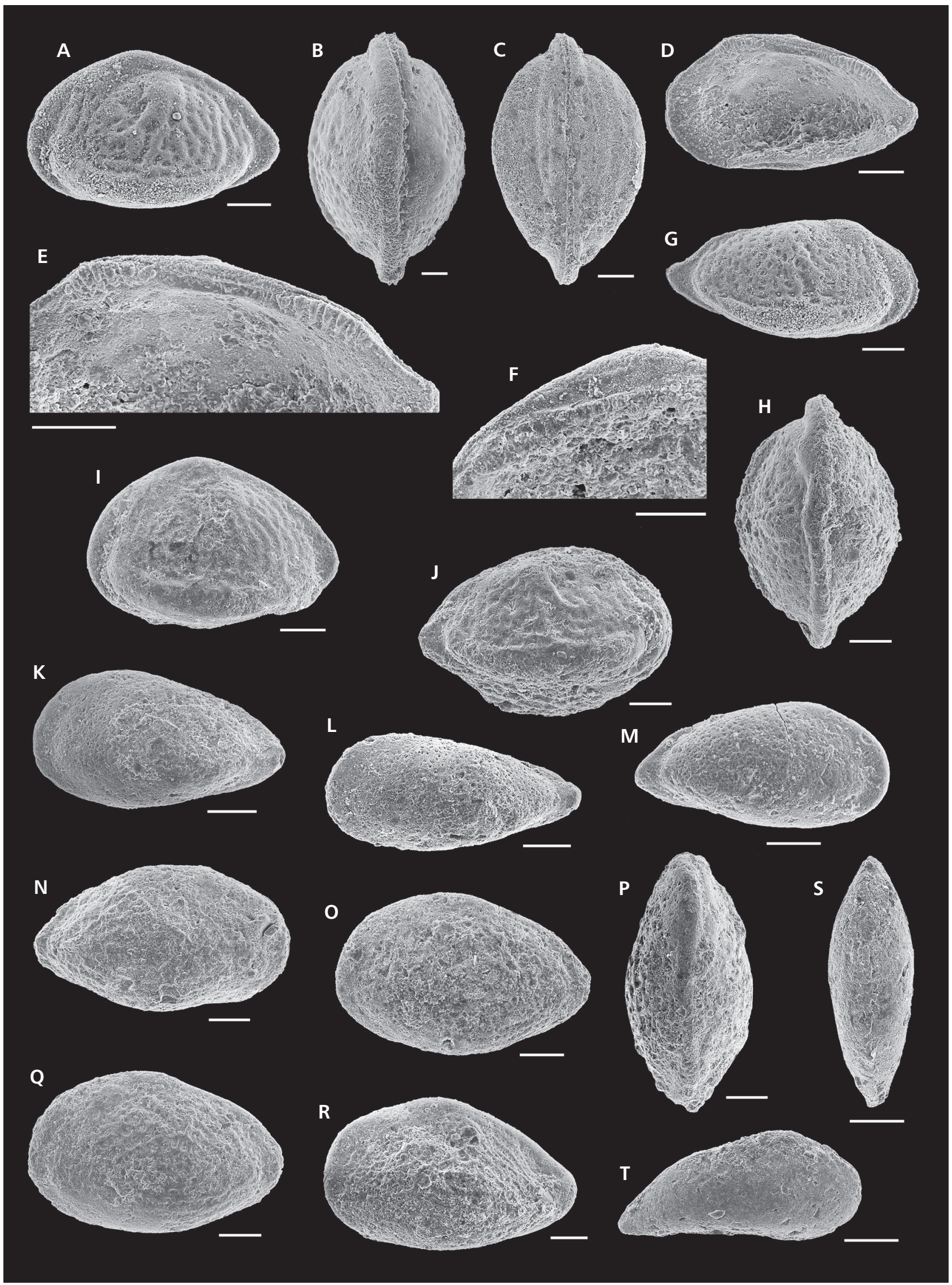


Genus Paracypris Sars, 1866

Type species. - Paracypris polita Sars, 1866.

\section{Paracypris cf. $P$. redcarensis (Blake, 1876)}

Figure 9S, T

cf. 1876 Bairdia redcarensis sp. nov.; Blake, p. 431, pl. 17, fig. 4.

2007 Paracypris cf. redcarensis (Blake). - Pinto et al., pl. 2, figs 4, 5 .

2016 Paracypris redcarensis (Blake). - Rocha et al., figs 4, 8.11 .

Material. -6 adult $\mathrm{C}, 1$ juvenile $\mathrm{C}$.

Remarks. - Paracypris cf. redcarensis Blake, 1876 has been frequently and probably erroneously recorded from many localities in Europe. The Peniche material consists of seven specimens in all biozones except the levisoni and differs from $P$. cf. redcarensis figured by Ainsworth (1987) from the Pliensbachian of the Fastnet Basin in being more elongate with a more concave ventral margin and an anterior margin more ventrally inclined. The original illustration of Blake, a small line drawing of a Hettangian specimen from Yorkshire, Great Britain, shows weaker cardinal angles and a less concave ventral margin than our material. This is a "Lazarus" taxon absent during the CIE and reappears in the bifrons Biozone.

Occurrence. - Pliensbachian, emaciatum Biozone; Toarcian, polymorphum and bifrons biozones.

Superfamily Macrocypridoidea Müller, 1912

Family Macrocyprididae Müller, 1912

\section{Genus Macrocypris Brady, 1867}

Type species. - Cythere minna Baird, 1850.
?Macrocypris cf. ?M. liassica Bate \& Coleman, 1975

Figure $10 \mathrm{~A}-\mathrm{C}$

cf. 1975 Macrocypris? liassica sp. nov.; Bate \& Coleman, p. 6, pl. 9.3, 9.6, 9.7, fig. 5 .

Material. -15 adult $\mathrm{C}$.

Remarks. - Our limited material is similar to the holotype (carapace right view, but not the juvenile paratypes) of ?M. liassica from the basal Toarcian of Great Britain but differs in being relatively shorter with a less extended posterior margin.

Occurrence. - Toarcian, bifrons Biozone.

Superfamily Pontocypridoidea G.W. Müller, 1894

Family Pontocyprididae G.W. Müller, 1894

\section{Genus Liasina Gramann, 1963}

Type species. - Liasina vestibulifera Gramann, 1963.

Remarks. - The species Liasina lanceolata (Apostolescu, 1959), described from the Sinemurian and Pliensbachian of the Paris Basin, is abundant ( $c a .450$ specimens, mostly $\mathrm{C}$, adults and juveniles) in the emaciatum, polymorphum and lower levisoni biozones of Peniche (Fig. 10H-J), and L. vestibulifera, described from the Lower Pliensbachian of NW Germany, is common ( $c a .35$ specimens, mostly $\mathrm{C}$, adults and juveniles) as $L$. cf. L. vestibulifera (Fig. 10K-M) in the emaciatum and polymorphum biozones. Internal information is lacking for both species but from external morphology we are confident about the identification of L. lanceolata although our specimens of $L$. cf. $L$. vestibulifera are less elongate and with a slightly convex ventral margin than in the figured type material.

Figure 10. Toarcian ostracods from Peniche section, Portugal. $-\mathrm{A}-\mathrm{C}-$ ?Macrocypris cf. ?M. liassica Bate \& Coleman, 1975, bifrons Biozone, sample P-404; A - carapace, right view, SMF Xe 23904, $\mathrm{L}=0.40, \mathrm{~h}=0.23$; B - carapace, left view, SMF Xe 23905, $\mathrm{L}=0.38, \mathrm{~h}=0.19$; C - carapace, dorsal view, SMF Xe 23906, $\mathrm{L}=0.38, \mathrm{~h}=0.20 . \cdot \mathrm{D}-\mathrm{G}-$ ?Liasina cylindrica Ainsworth, 1986, polymorphum and bifrons biozones; $\mathrm{D}-$ carapace, dorsal view, SMF Xe 23907, $\mathrm{L}=0.38, \mathrm{~h}=0.18$, polymorphum Biozone, sample P11B; E - carapace, right view, SMF Xe 23908, $\mathrm{L}=040, \mathrm{~h}=0.19$, polymorphum Biozone, sample P23; F - carapace, right view, SMF Xe 23909, L =0.39, h = 0.18, bifrons Biozone, sample P422; G - carapace, left view, SMF Xe 23910, $\mathrm{L}=0.40, \mathrm{~h}=0.20$, bifrons Biozone, sample P422. - H-J - Liasina lanceolata (Apostolescu, 1959), polymorphum Biozone, sample P23; H - LV, external view, SMF Xe 23911, L = 0.53, h = 0.25; I - carapace, right view, SMF Xe 23912, L = 0.51, h = 0.25; J - carapace, dorsal view, SMF Xe 23913, $\mathrm{L}=0.55, \mathrm{~h}=0.26 . \cdot \mathrm{K}-\mathrm{M}$ - Liasina $\mathrm{cf}$. L. vestibulifera Gramann, 1963, polymorphum Biozone; $\mathrm{K}$ - carapace, dorsal view, SMF Xe 23914, L = 0.45, h =0.23, sample P6; L - carapace, left view, SMF Xe 23915, L = 0.48, h =0.23, sample P4; M - carapace, right view, SMF Xe 23916, $\mathrm{L}=0.42, \mathrm{~h}=0.20$, sample P3T. $・ \mathrm{~N}, \mathrm{O}$ - Cardobairdia fastnetensis Ainsworth, 1986, bifrons Biozone; N - carapace, right view, SMF Xe 23917, L = 0.45, h = 0.25, sample P386A; O - carapace, left view, SMF Xe 23918, L = 0.42, h = 0.24, sample P392. • P, Q - Cardobairdia aff. C. posteroprolata Ainsworth, 1987, bifrons Biozone, sample P414; P - carapace, left view, SMF Xe 23919, L = 0.44, h = 0.24; Q - carapace, right view, SMF Xe 23920, $\mathrm{L}=0.44, \mathrm{~h}=0.21$. $\mathrm{R}, \mathrm{S}-$ Cardobairdia $\mathrm{cf}$. C. sp. A Ainsworth, 1987, polymorphum Biozone; $\mathrm{R}-\mathrm{LV}$, external view, SMF Xe 23921, L = 0.42, h = 0.30, sample P6; S - carapace, right view, SMF Xe 23922, L =0.41, h = 0.32, sample P11B. • T, U - Cardobairdia sp. 1, bifrons Biozone, sample P381; T - carapace, right view, SMF Xe 23923, L = 0.42, h =0.30; U - carapace, left view, SMF Xe 23924, L =0.43, h = 0.30. Dimensions in $\mathrm{mm}$. Scale bars $=100 \mu \mathrm{m}$ 


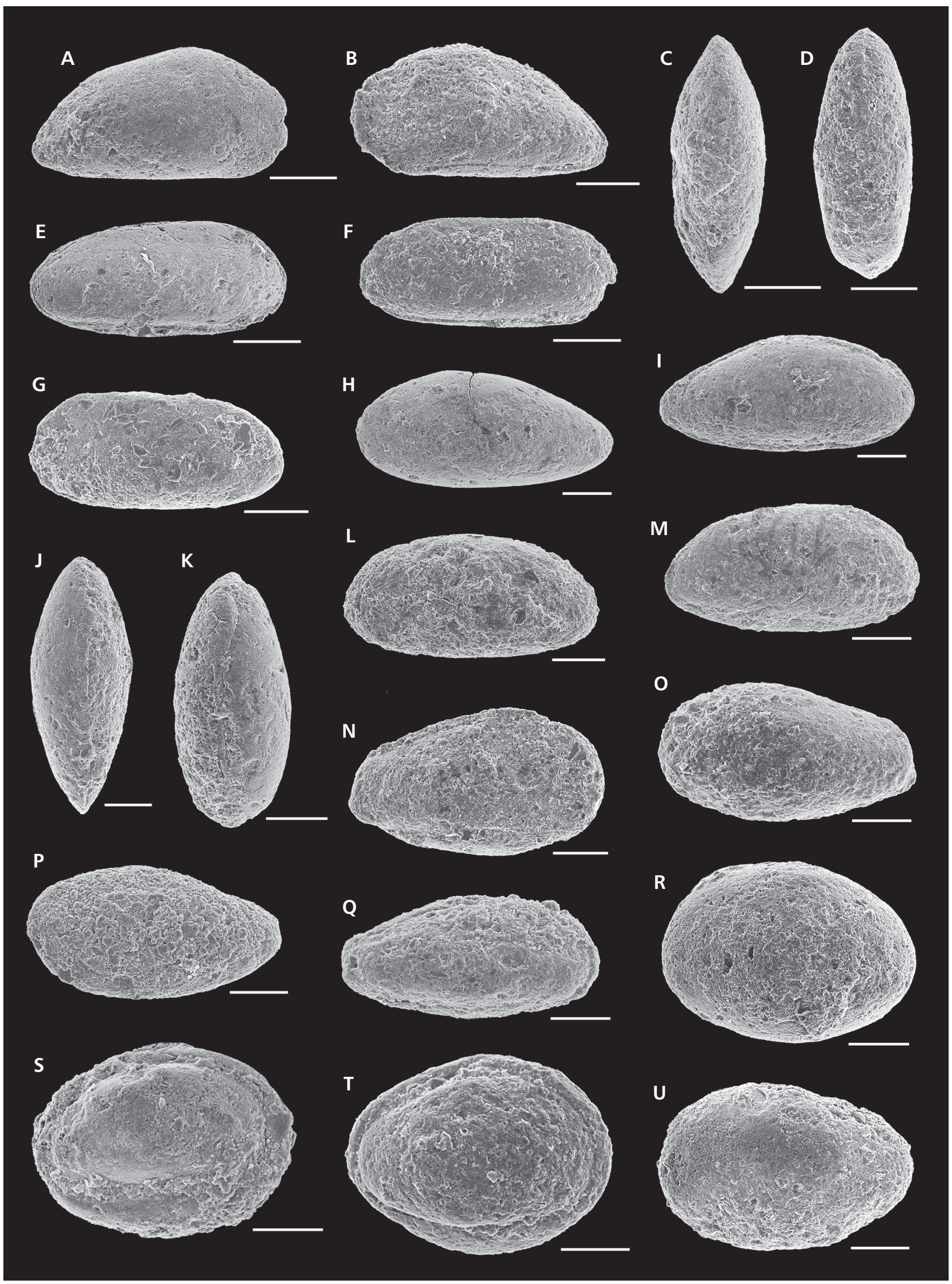


?Liasina cylindrica Ainsworth, 1986

Figure 10D-G

1986 Liasina? cylindrica sp. nov.; Ainsworth, pp. 298, 299, pl. 4, figs 1, 2, 5 .

1999a Liasina aff. Liasina vestibulifera Gramann, 1963. Arias \& Lord, p. 90, pl. 3, fig. 6.

2007 Isobythocypris cf. tatei (Coryell, 1963). - Pinto et al., pl. 1, figs 7, 8 .

2016 Isobythocypris tatei. - Rocha et al., fig. 4.

Material. $-\mathrm{Ca} .35$ specimens, mostly adult and juvenile C.

Remarks. - ?Liasina cylindrica is an important species in the polymorphum Biozone at Peniche and Rabaçal; it is present in the bottom sample of the CIE and then reappears as a "survivor" species in the bifrons Biozone. Our material appears identical with Ainsworth's species cylindrica from the late Toarcian and Aalenian of the Fastnet Basin. We are uncertain if the species belongs to Liasina as we have no information about the internal features. The carapace shape does not match Isobythocypris Apostolescu.

The name "tatei" proposed by Coryell (1963) as a replacement for Bairdia elongata Blake, 1876 has become greatly confused in the literature, authors having followed Drexler's (1958, p. 515, pl. 23, fig. 1a-f, pl. 26, figs 7-9, pl. 27, figs 1,2) incorrect identification of "Bythocypris cf. elongata (Tate \& Blake 1876)".

Occurrence. - Pliensbachian, emaciatum Biozone; Toarcian, polymorphum, levisoni and bifrons biozones.

Suborder Sigilliocopina Mandelstam, 1960

Superfamily Sigillioidea Mandelstam, 1960

Family Saipanettidae McKenzie, 1968

\section{Genus Cardobairdia Van den Bold, 1960}

Type species. - Cardobairdia ovata Van den Bold, 1960.

Remarks. - A few specimens of four species of Cardobairdia occur in the topmost Pliensbachian (emaciatum Biozone) and Toarcian (polymorphum and bifrons biozones) of Peniche. In the emaciatum and polymorphum biozones a rounded form comparable to Cardobairdia sp. A of Ainsworth (1987) described from the Pliensbachian of the Fastnet Basin is present, represented by $c a .20$ adult V (Fig. 10R, S). In the bifrons Biozone occur: an elongated form (4 adult $\mathrm{C}$ ) with postero-ventral margin of the RV extended beyond posterior of LV, identified as Cardobairdia fastnetensis Ainsworth, 1986 (Fig. 10N, O), from the Toarcian of the Fastnet Basin; another elongated form (12 adult C), closer to C. fastnetensis but with a more convex dorsal margin and without the postero-ventral margin of the RV extended beyond posterior of LV, identified as $C$. aff. C. posteroprolata Ainsworth, 1987 (Fig. 10P, Q); a rounded to subtriangular form (5 adult $\mathrm{C}$ ), named Cardobairdia sp. 1 (Fig. 10T, U) which is less rounded and has weaker overlap than Cardobairdia sp. A of Ainsworth.

\section{Results and discussion}

\section{Peniche ostracod assemblages}

Ostracods are well represented, with more than 7,000 specimens (at least 52 species, belonging to 22 genera) found along the studied section, irregularly distributed, more abundant in polymorphum and bifrons biozones, very rare in levisoni Biozone. The assemblages show marked changes between the lower and upper levels (Fig. 11).

In analysing the ostracod species occurrences we distinguish between "Lazarus" and "survivor" species, although in a conventional sense both are "Lazarus" taxa in that they have migrated to a more favourable habitat, in this case presumably more oxygenated bottom waters, and returned when favourable conditions were re-established. We differentiate "Lazarus" species as those that do not occur in the CIE interval but reappear later, as opposed to "survivor" species that occur in the lowermost sample in the CIE and reappear later, post-CIE. Thus "Lazarus" species are: Bairdia aff. B. molesta (reappears higher in levisoni Biozone, post-CIE) and Paracypris cf. $P$. redcarensis (reappears in bifrons Biozone); "survivor" species are ?Liasina cylindrica (reappears in bifrons Biozone) and Kinkelinella sermoisensis (reappears higher in levisoni Biozone, post-CIE). Note that in Fig. 11 the apparent "survivor" taxon in the left column is an artificial group (Polycope spp.) and that the right column showing the occurrence of unidentifiable ostracods includes specimens throughout the CIE interval.

In the Upper Pliensbachian emaciatum Biozone ostracods are very poorly preserved (mostly valves), making it impossible to identify many specimens and therefore the data are certainly incomplete, requiring caution in their interpretation. The assemblages showed relatively moderate diversity (= number of species) with $c a$. 14 spp., coincident with the first negative $\delta^{13} \mathrm{C}$ excursion (Horizon 1 of Hesselbo et al. 2007, figs 2, 3; Littler et al. 2010; Fig. 2 here) and perhaps reflecting relatively low sea level towards the end of that stage (see Duarte 2007, Duarte et al. 2010). However, all the identified species range into the Toarcian, except Cytherella sp., and assemblages became more diverse in the Toarcian polymorphum Biozone with up to 26 species in total (e.g. sample P11B: 20 spp., P23: 16 spp.). Besides exhibiting high diversity, 


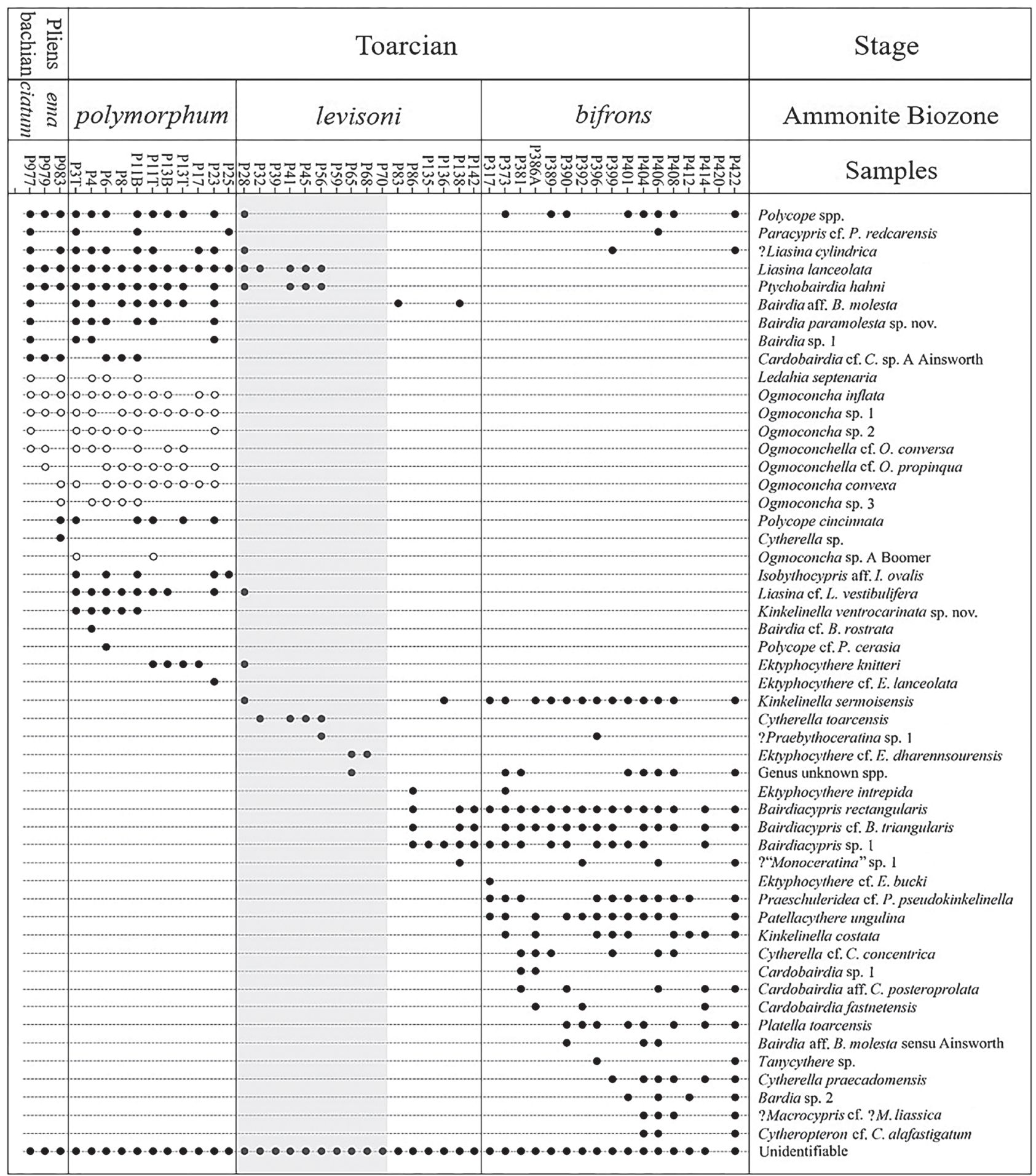

Figure 11. Ostracod distribution chart (black dots, except Metacopina represented by open circles) for the studied Peniche section. The CIE interval, as referred to in this paper, is shown in grey. Biozone divisions are not to scale.

ostracods are abundant, usually more carapaces but $\mathrm{V}>$ $\mathrm{C}$ in some levels; Metacopina are dominant ( 9 species), Bairdidae well represented and new species appear such as Ektyphocythere knitteri and Kinkelinella ventrocarinata sp. nov., the latter recorded only in the polymorphum Biozone.
Of the nine metacopine species recognized eight ranged across the Pliensbachian-Toarcian boundary. All the metacopine taxa became extinct just before the polymorphum-levisoni boundary prior to the onset of the CIE conditions in the LB, but coincident with a previous 
discrete negative pulse of the isotope curve (Fig. 12). The extinctions appear stepwise in the order: Ledahia septenaria and Ogmoconcha sp. 3, Ogmoconcha sp. A Boomer, Ogmoconchella cf. $O$. conversa, followed by simultaneous last occurrences of Ogmoconcha inflata, O. convexa, $O$. sp. 1,O. sp. 2, and Ogmoconchella cf. O. propinqua. However, this sequence is likely to be an artefact of sampling resolution, taphonomy, preservation and/or identification given the large number of unidentifiable specimens.

In the lower levisoni Biozone (= CIE, between horizons 2 and 3 of Hesselbo et al. 2007, figs 2,3) there were few ostracods and diversity was drastically reduced from seven species at the base (sample P-28) and then fluctuating between four (P-56), three (P-41, P-45), two (P-32, $\mathrm{P}-65)$, one (P-68) and even zero (P-39, P-59, P-70); the two species Cytherella toarcensis and Ektyphocythere cf. $E$. dharennsourensis are only known in this interval and seem adapted to the bottom water conditions. Higher in the levisoni Biozone, post-CIE, the number of ostracods and diversity remained low with one "survivor" species (K. sermoisensis), one "Lazarus" species (B. aff. B. mole$s t a)$ and five new species (Bairdiacypris rectangularis, B. cf. B. triangularis, B. sp. 1, Ektyphocythere intrepida, ?"Monoceratina" sp. 1). In these levels (intra and postCIE), ostracods are mostly represented by carapaces.

In the bifrons Biozone ostracods are relatively abundant (mostly carapaces), diversity steadily increased from moderate to high, namely from 6 in the lower part (P-317) to 17 in the upper part (P-422), with 15 new to the zone, 8 ranging from the levisoni Biozone below and 3 from polymorphum Biozone. The most important species in this bifrons biozone, abundantly represented belong to the genera Bairdiacypris, Kinkelinella and Cytherellal Platella.

\section{Ostracod palaeobiogeography and the Carbon Isotope Excursion regionally}

The CIE reflects an injection of isotopically light carbon into the atmosphere which is preserved in the sedimentary and palaeontological record (e.g. Hesselbo et al. 2007, Ruebsam et al. 2019). While this process did not control the occurrence of ostracods directly it did ultimately affect bottom water oxygenation, which was low (dysoxic to possibly anoxic conditions) in several palaeogeographic contexts (e.g. Schmid-Röhl et al. 2002, Jenkyns 2010, Ruebsam et al. 2019). In northwestern and central European regions, very low or no oxygen conditions are commonly represented by "paper" shales (e.g. 'schistes carton' in France - e.g. Andreu et al. 1995) which lack bottom water biota and bioturbation and preserved fossils are of planktonic and nektonic organisms. At Peniche, despite the strong pertubation of the benthic, nektonic and planktonic records in this interval (Mattioli et al. 2009; Cabral et al. 2011, 2013; Comas-Rengifo et al. 2015; Rita et al. 2016; Correia et al. 2017), the low total organic carbon content and the absence of redox-sensitive traces confirm absence of anoxia (e.g. Hesselbo et al. 2007, Fantasia et al. 2019). This model is also supported by the turbiditic sedimentation recorded across the base of the levisoni Biozone (Wright \& Wilson 1984, Duarte 1997).

For the LB the CIE is assigned to a hyperthermal event (Suan et al. 2008, 2010). However, the ostracods described here provide no bottom water temperature information. The genus Cytherelloidea Alexander conventionally regarded as a warm water indicator in modern seas did not occur in Peniche material. Gómez \& Arias (2010) estimated seawater palaeotemperature variations based on stable isotope analyses of belemnite calcite from two sections located in the Iberian Range, central Spain and compared them with range data for ostracods, brachiopods and bivalves. During the Early Toarcian tenuicostatum (= polymorphum) Biozone they noted that a decrease in the number of ostracod species coincided with a warning trend, marking an "extinction interval" whose limit is located around the tenuicostatum-serpentinum (= levisoni) biozones boundary and characterized by the loss of all Metacopina Taxa (MEE, see next paragraph).

Boomer et al. (2008) coined the term Metacopine Extinction Event (MEE) based on assemblages from the Mochras Farm Borehole, west Wales, U.K. This borehole penetrated a very extended Lower Jurassic sequence of $1305 \mathrm{~m}$ of marine sediments which has been extensively studied, especially for its geochemical and microfossil records. Some ostracod data have been published (Boomer 1991) but not detailed species ranges. Ian Boomer (personal communication 2019) has generously given us access to his range data related to the CIE in the Mochras Farm Borehole, which allows direct and accurate correlation with our Peniche isotope record via the $\delta^{13} \mathrm{C}$ curve in this interval (horizons 2 and 3 of Hesselbo et al. 2007; Xu et al. 2018) and thereby comparison of the ostracod ranges. There are surprising similarities and differences in detail of the occurrence patterns of the ostracod species common between the two sites; discussion here is limited to taxa we are confident are the same or very close. The MEE at Peniche (Fig. 12) falls at the top of the polymorphum Biozone, before the CIE, but coincident with the previous discrete negative pulse of the isotope curve; however, in the Mochras Farm Borehole the last metacopines became extinct within the CIE, i.e. at the base of the falciferum Biozone, equivalent to the levisoni Biozone used here (Boomer et al. 2008, fig. 2 for basic $\delta^{13} \mathrm{C}$ plot against metacopine abundance), suggesting that the event was not synchronous between the Lusitanian Basin and the Cardigan Bay Basin and supporting the idea of the MEE becoming later northwards (see discussion in 


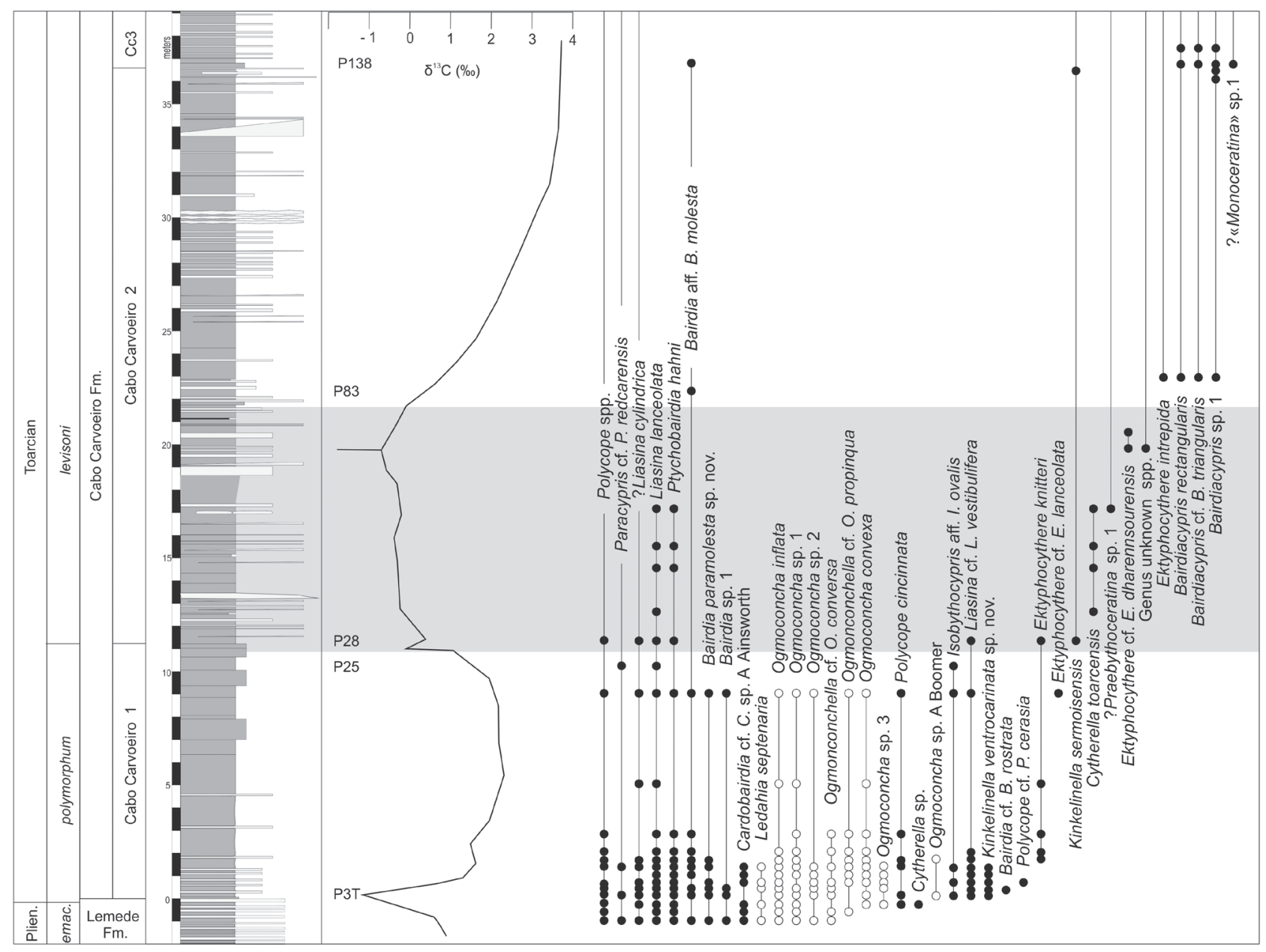

Figure 12. Stratigraphical distribution of the ostracod species (black dots, except Metacopina represented by open circles) through the emaciatum, polymorphum and levisoni ammonite biozones in Peniche section. The CIE as referred to in this paper (between horizons 2 and 3 of Hesselbo et al. 2007, figs 2 and 3) is shown in grey. The numbers to the left of the isotope curve correspond to selected samples to help follow the succession. Lithological symbols and References as in Fig. 2.

Boomer et al. 2008, pp. 48, 49). Even in the LB it seems not synchronous between Peniche and Rabaçal, located slightly to the North where the MEE is recorded at the polymorphum-levisoni boundary, as discussed in Cabral et al. (2013). However, as also discussed in Boomer et al. (2008), the comparison of the precise timing of the MEE between different sites is debatable, as it significantly depends on resolution of sampling intervals, quality of biostratigraphic control and variations in sedimentationrate that vary with sites and authors.

Comparing ostracod records between Peniche and the Mochras Farm Borehole the following similarities occur: (i) Both Liasina lanceolata and L. vestibulifera range into the CIE and then become extinct; in both places L. lanceolata was relatively common in the CIE assemblages; (ii) Paracypris redcarensis (our P. cf. P. redcarensis) is a "Lazarus" taxon in both sites; (iii) the following species appear above the CIE at Peniche and Mochras Farm:
Bairdiacypris rectangularis, B. triangularis (our taxon is cf.), Ektyphocythere intrepida, Kinkelinella sermoisensis (it is a "survivor" species at Peniche where it also occurs at the base of the CIE); (iv) in both places Cytherella praecadomensis and Cytheropteron alafastigatum appear in the bifrons Biozone. However, there are differences in detail: (i) Cytherella toarcensis occurs only in the CIE interval at Peniche where, together with $L$. lanceolata, it is the most common taxon, however, at Mochras Farm C. toarcensis occurs much higher in the variabilis (= gradata) Biozone; (ii) Praeschuleridea pseudokinkelinella appears at Mochras Farm at the top of the CIE whereas in Peniche it appears at the base of the bifrons Biozone; (iii) Ektyphocythere cf. E. lanceolata occurs at the top of the polymorphum Biozone at Peniche whereas E. lanceolata appears higher in the bifrons Biozone at Mochras Farm; (iv) Polycope cincinnata seems to become extinct in Peniche at the top of the polymorphum Biozone, before 
the CIE, but at Mochras Farm it ranges into the CIE before becoming extinct.

It is unusual to be able to compare species ranges so finely over such a long distance $(c a .1,500 \mathrm{~km})$ but the CIE provides the correlation confidence. Unfortunately, while there is an increasing number of high-resolution isotope records for early Toarcian age sections there are few detailed ostracod biostratigraphic studies to link to them to compare with Peniche. Where the isotope and other geochemical data are good the ostracod record is poor or unknown e.g. Yorkshire coast, Great Britain.

Arias (2006) gives isotope data and selected ostracod ranges for the Upper Pliensbachian-Lower Toarcian interval for the Almonacid de la Cuba section, Cordillera Iberica (Iberian Range), NE Spain. However, the $\delta^{13} \mathrm{C}$ and $\delta^{18} \mathrm{O}$ records are based on few data points and the ostracod range chart is focussed on the Pliensbachian-Toarcian boundary interval and only confirms that the MEE falls in the mirabile Subbiozone, polymorphum Biozone, that Liasina lanceolata ranges through the interval and that, in contrast to Peniche, Cytherella toarcensis appears in the Upper Pliensbachian spinatum (= emaciatum) Biozone. Also from the Cordillera Iberica, Gómez et al. (2008) gave ostracod ranges for the La Almunia de Doña GodinaRicla section against the $\delta^{13} \mathrm{C}$ curve. The ostracod ranges, modified after Arias (unpublished data 1995, 1996), show the MEE falling in the paltum Subbiozone (equivalent to the mirabile Subbiozone). The $\delta^{13} \mathrm{C}$ is positive over the interval equivalent to the polymorphum Biozone at Peniche but it is possible to make some comparisons between the two sites. Liasina lanceolata becomes extinct at about the same level, as do L. vestibulifera and Polycope cincinnata; Ektyphocythere sermoisensis, Praeschuleridea pseudokinkelinella and Praebythoceratina ungulina appear at approximately equivalent levels, whereas Cytherella toarcensis has a local range in the polymorphum Biozone equivalent and Ektyphocythere dharennsourensis ranges through the interval but in Peniche has a short appearance at the top of the CIE. Gómez \& Goy (2011) reporting on ostracods and isotopes from Sierra Palomera in the Cordillera Iberica give only $\delta^{18} \mathrm{O}$ curves and the ostracod range chart is exactly the same as published by Gómez et al. (2008) for La Almunia de Doña Godina-Ricla.

Exton \& Gradstein (1984) report Early Jurassic ostracods from the Grand Banks, offshore eastern Canada, and compare them with material from a number of Portuguese localities especially Rabaçal. Their record from the Pliensbachian through the Toarcian is generalized and shows a number of taxa that are the same or reinterpreted here, with a marked faunal turnover and extinction of the metacopines in the early Toarcian, however it is not possible to recognise the CIE (or T-OAE) in detail. Similarly, the record from Rabaçal (= Zambujal) in Boomer et al. (1998) is also rather generalized and shows the extinction of the Metacopina in the lower tenuicostatum Biozone (= polymorphum Biozone), whereas in our material (Cabral et al. 2013) the final extinction level is in the upper part of the polymorphum Biozone at Peniche and at the polymorphum/levisoni boundary at Rabaçal, which shows that the ammonite zonation in Boomer et al. (1998) requires adjustment.

From discussion above and considering the occurrence records referred in Systematic Palaeontology it is clear that for reasons of palaeogeographical proximity and palaeoceanographical patterns the Toarcian ostracod assemblages of Peniche (and Rabaçal) are very close to those described from offshore southwest Ireland, particularly in Fastnet Basin, and the western UK and less so to those described from eastern Spain. At species level (including cf. and aff. levels) a number of taxa described from France and Germany have also been recognized. The broad pattern of faunal turnover and replacement before, during and after the CIE, including "survivor" and "Lazarus" species, and the stepwise extinction of metacopine ostracods prior to the CIE is similar but not identical to that described, for example, from the Mochras Farm Borehole (Boomer 1991, personal communication 2019) and Ilminster (Boomer et al. 2009), Great Britain, north-eastern Spain (e.g. Arias 2009), Aquitaine Basin (Andreu et al. 1995) and Paris Basin (Apostolescu 1959), France, SW Germany (Riegraf 1985, Franz et al. 2009) and NW Switzerland (Richter 1987). Riegraf (1985, fig. 14) gives a good summary of "Lazarus" taxa of ostracods and foraminifera before, during and after deposition of the early Toarcian bituminous paper shales of the Posidonienschiefer in SW Germany. A number of important taxonomic papers by Herrig (e.g. 1979, 1985) describe Lower Jurassic material from E Germany but lack detailed biostratigraphic data. Monostori (2008) reports that metacopes are absent in the basal Toarcian tenuicostatum Biozone (= polymorphum Biozone) of Transdanubian Hungary and attributes this to a sudden deepening of a subsiding basin in that area.

We do not discuss ostracod records from outside Europe because none has companion isotope data.

\section{Extinction of the Suborder Metacopina}

It has long been known that the extinction of a major group of ostracods, the Metacopina, occurred in the early Toarcian and appears to coincide with the initiation of the Toarcian reduced bottom water oxygen conditions (e.g. Boomer et al. 2008). At Peniche the extinction of nine metacopine species in the polymorphum Biozone, including five in the penultimate sample (P-23), would appear to confirm a causal relationship but in detail it can be seen that the extinctions preceded the decrease of 
the bottom water oxygen conditions at a global scale, as represented by the CIE (and macrofossil impoverishment as described above) and occurred in a step-wise pattern. The relationship between the living ostracods and bottom water oxygenation is unlikely to have been simple and other factors such as bottom water temperature and $\mathrm{pH}$ may have played a part in the species extinctions, as discussed by previous authors about the T-OAE (e.g. Gómez et al. 2008; Suan et al. 2008, 2010; Gómez \& Arias 2010; Trecalli et al. 2012). The highest polymorphum Biozone sample (P-25) contains ostracods but no metacopine taxa. As has been observed (Lord 1982, Boomer et al. 2008) an oxygen minimum zone (OMZ), no matter how global in scale it was, does not in isolation explain the metacopine extinction event when at Peniche and elsewhere, e.g. Mochras Farm Borehole, SW Germany, "Lazarus" taxa survived in refugia and were able to recolonize when bottom water conditions improved. The early Toarcian is now one of the most intensely studied time intervals in the Phanerozoic from a wide variety of geochemical, geophysical, palaeoclimatological, palaeoceanographical and palaeobiological perspectives but despite the wealth of data the explanation for the extinction of the metacopine ostracods remains unclear.

Having survived at least three major extinction events the question is what was unique about the early Toarcian environment that proved fatal to the group? Boomer et al. (2008) argued that competition for space and resources with other ostracod groups that had evolved rapidly in the Early Jurassic was a key factor, but probably not the only one, in the extinction of the group.

The fragmentation of the Pangea supercontinent undoubtedly greatly increased the area of epicontinental shelves, perhaps especially in NW Europe, which seems to have facilitated the dramatic evolutionary expansion of cytherocopes in Early Jurassic time. Cytherocopes possess smaller size and more complex marginal zones than metacopes which may have conferred an adaptive advantage. Early Jurassic cytherocopes have relatively simple, straight marginal pore canals with more complex forms developing through the Mesozoic. Similarly, normal pore canals were generally simple but more complex sieve-type pores evolved in parallel during the Early Jurassic (Lord et al. 2020).

\section{Conclusions}

(1) The ostracod assemblages of the uppermost Pliensbachian (emaciatum Biozone) and Lower-Middle Toarcian (polymorphum, levisoni and bifrons biozones), which encompasses the GSSP and the T-OAE as represented by the CIE, at Peniche, western Portugal, were studied in systematic detail for the first time.
(2) All the studied ostracods are typical marine as expected in this open marine marl-limestone series.

(3) The ostracods are poorly preserved and from the $c a$. 7,000 specimens found, at least 52 species (belonging to 22 genera) are identified.

(4) The following species are recognized as new: Bairdia paramolesta Cabral, Lord \& Pinto sp. nov., Kinkelinella ventrocarinata Cabral, Pinto \& Lord sp. nov.

(5) The ostracods from the GSSP demonstrate major faunal turnover, more clearly than in other benthic taxa: in the polymorphum Biozone diversity was relatively high with at least 26 species from which nine belong to the Metacopina, but in the lower levisoni Biozone (CIE interval) diversity was drastically reduced to seven species and then to four to one; higher in the levisoni Biozone (post-CIE) diversity remained low with one "survivor" species, one "Lazarus" species and five new species (three belonging to the genus Bairdiacypris). In the CIE three species are most common: Liasina lanceolata, Ptychobairdia hahni and Cytherella toarcensis; this latter species and Ektyphocythere cf. E. dharennsourensis only occur in the low oxygen zone.

(6) Metacopina species showed a stepwise extinction pattern and all disappeared before the polymorphumlevisoni biozonal boundary prior to the marked onset of CIE conditions. Correlation with the Mochras Farm Borehole suggests that the MEE was not synchronous and earlier at Peniche.

(7) The $\delta^{13} \mathrm{C}$ record at Peniche and the Mochras Farm Borehole facilitates a very refined comparison of ranges of species in common between the two sites.

(8) The ostracod assemblages from Peniche are closer to those from the western Europe, particularly from Great Britain and offshore Ireland for the same age.

(9) The broad pattern of faunal turnover and replacement in the Peniche section before, during and after the CIE, including "survivor" and "Lazarus" species, and the stepwise extinction of metacopine ostracods prior to the CIE is similar to that described from elsewhere in Western Europe.

\section{Acknowledgements}

We thank Ian Boomer (University of Birmingham) for access to unpublished information. We are indebted to Vera Lopes (University of Lisbon) and Telmo Nunes (University of Lisbon) 
for technical help with figure preparation and SEM imaging respectively. We also thank the reviewers Ian Boomer and Wolfgang Mette (Austria) for the helpful comments on the manuscript. Maria Cristina Cabral and A.C. Azerêdo were supported by FCT-project UIDB/50019/2020 - Instituto Dom Luiz (IDL), University of Lisbon. Luís V. Duarte was supported by FCT - project UIDB/04292/2020 granted to the Marine and Environmental Sciences Centre (MARE, Portugal). This is a contribution to Project IGCP 655, Toarcian Oceanic Anoxic Event: Impact on marine carbon cycle and ecosystems. Included in the thematic area of "Global Change and the Evolution of life: evidence from the geological record, supported by UNESCO and IUGS.

\section{References}

Adamczak, F. 1967. Morphology of two Silurian metacope ostracodes from Gotland. Geologiska Föreningens $i$ Stockholm Förhandlingar 88, 462-475.

DOI 10.1080/11035896709455503

AdAMCZAK, F. 1976. Morphology and Carapace Ultrastructure of some Healdiidae (Ostracoda). Abhandlungen und Verhandlungen des Naturwissenschaftlichen Vereins in Hamburg, New Series 18/19 (Suppl.), 315-318.

Ainsworth, N.R. 1986. Toarcian and Aalenian Ostracoda from the Fastnet Basin, offshore southwest Ireland. Geological Survey of Ireland Bulletin 3, 277-336.

Ainsworth, N.R. 1987. Pliensbachian Ostracoda from the Fastnet Basin, offshore Southwest Ireland. Geological Survey of Ireland Bulletin 4, 41-62.

Ainsworth, N.R. 1989. Remarks on the nomenclature of two ostracod species from the Pliensbachian and Upper ToarcianAalenian of the Fastnet Basin, offshore southwest Ireland. Geological Survey of Ireland Bulletin 4, 165-166.

Ainsworth, N.R. \& Boomer, I. 2009. Lower Jurassic (HettangianToarcian), 175-197. In WhitTAKer, J.E. \& HART, M.B. (eds) Ostracods in British Stratigraphy. The Micropalaeontological Society Special Publication. Geological Society, London.

Andreu, B., Qajoun, A. \& Cubaynes, R. 1995. Ostracodes du Toarcien du Quercy (Bassin d'Aquitaine, France): systématique, biostratigraphie et paléobiogéographie. Geobios 28, 209-240. DOI 10.1016/S0016-6995(95)80229-0

Apostolescu, V. 1959. Ostracodes du Lias du Bassin de Paris. Revue de l'Institut Français du Petrole 14, 795-826.

ARIAS, C. 2006. Changes in ostracod provincialism during the early Toarcian in the European epicontinental sea-western Tethys area. Revista Española de Micropaleontología 38, 245-267.

ARIAS, C. 2009. Extinction pattern of marine Ostracoda across the Pliensbachian-Toarcian boundary in the Cordillera Ibérica, NE Spain: Causes and consequences. Geobios 42, 1-15. DOI 10.1016/j.geobios.2008.09.004

Arias, C. \& Lord, A.R. 1999a. Upper Pliensbachian and Lower Toarcian Ostracoda from the Cordillera Ibérica, north-east Spain. Part I. Revista Española de Micropaleontologia 31, 73-98.
Arias, C. \& LoRd, A.R. 1999b. Upper Pliensbachian and Lower Toarcian Ostracoda from the Cordillera Ibérica, north-east Spain. Part II. Revista Española de Micropaleontologia 31, 219-242.

Azerêdo, A.C., Duarte, L.V., Henriques, M.H. \& Manuppella, G. 2003. Da dinâmica continental no Triásico aos mares no Jurássico Inferior e Médio. 43 pp. Cadernos de Geologia de Portugal, Instituto Geológico e Mineiro, Lisboa.

BAIRD, W. 1845. Arrangement of the British Entomostraca, with a list of species, particularly noticing those which have as yet been discovered within the bounds of the Club. Transactions of the Berwickshire Naturalists' Club 2, 145-158.

BAIRD, W. 1850. The Natural History of the British Entomostraca. 364 pp. The Ray Society, London. DOI 10.5962/bhl.title.1807

Bate, R.H. 1963. Middle Jurassic Ostracoda from North Lincolnshire. Bulletin of the British Museum (Natural History), Geology 8, 173-219.

Bate, R.H. 2009. Middle Jurassic (Aalenian-Bathonian), 175-197. In WhitTaKer, J.E. \& HaRT, M.B. (eds) Ostracods in British Stratigraphy. The Micropalaeontological Society Special Publication. Geological Society, London.

Bate, R.H. \& Coleman, B.E. 1975. Upper Lias Ostracoda from Rutland and Huntingdonshire. Bulletin of the Geological Survey of Great Britain 55, 1-42.

Bizon, J.-J. 1960. Sur quelques Ostracodes du Lias du Bassin Parisien. Revue de Micropaléontologie 2, 203-211.

Blake, J.F. 1876. Subclass Entomostraca, 429-435. In Tate, R. \& Blake, J.F. The Yorkshire Lias. 475 pp. John Van Voorst, London.

Boomer, I. 1988. On Ektyphocythere lanceolata Boomer sp. nov. A Stereo-Atlas of Ostracod Shells 15, 89-92.

Boomer, I. 1991. Lower Jurassic ostracod biozonation of the Mochras Borehole. Journal of Micropalaeontology 9, 205-218. DOI 10.1144/jm.9.2.205

Boomer, I. 1992. Lower Jurassic ostracods from Ilminster, Somerset, England. Journal of Micropalaeontology 11, 47-57. DOI 10.1144/jm.11.1.47

Boomer, I. \& Ainsworth, N.R. 2009. Lower Jurassic (HettangianToarcian), 175-197. In WhitTaker, J.E. \& Hart, M.B. (eds) Ostracods in British Stratigraphy. The Micropalaeontological Society Special Publication. Geological Society, London.

Boomer, I., Ainsworth, N.R. \& Exton, J. 1998. A re-examination of the Pliensbachian and Toarcian Ostracoda of Zambujal, west-central Portugal. Journal of Micropalaeontology 17, 1-14. DOI 10.1144/TMS003.8

Boomer, I., Lord, A. \& Crasquin, S. 2008. The extinction of the Metacopina (Ostracoda). Senckenbergiana lethaea 88, 47-53. DOI 10.1007/BF03043977

Boomer, I., Lord, A.R., Page, K.H., Bown, P.R., Lowry, F.M.D. \& Riding, J.B. 2009. The biostratigraphy of the Upper Pliensbachian-Toarcian (Lower Jurassic) sequence at Ilminster, Somerset. Journal of Micropalaeontology 28, 67-86. DOI 10.1144/jm.28.1.67

Boutakiout, M., Donze, P. \& Oumalch, F. 1982. Nouvelles espèces d'ostracodes du Lias moyen et supérieur du Jbel Dhar En Nsour (Rides sud-Rifaines, Maroc Septentrionale). Revue de Micropaléontologie 25, 94-104. 
Brady, G.S. 1867. A synopsis of the Recent British Ostracoda. The Intellectual Observer 12, 110-130.

Bradfield, H.H. 1935. Pennsylvanian Ostracoda of the Ardmore Basin, Oklahoma. Bulletins of American Paleontology 22(73), 1-173.

Brand, E. 1961. In Brand, E. \& Malz, H. Ostracoden-studien im Dogger, 3: drei neue Procytheridea-arten und Ljubimovella n.g. aus dem NW-Deutschen Bajocien. Senckenbergiana lethaea 42, 157-173.

Cabral, M.C., Colin, J.-P., Azerêdo, A.C., Silva, R.L. \& Duarte, L.V. 2015. Brackish and marine ostracode assemblages from the Sinemurian of western Portugal, with description of new species. Micropaleontology 61, 3-24.

Cabral, M.C., Lord, A.R., Boomer, I.D., Loureiro, I. \& Malz, H. 2014. Tanycythere new genus and its significance for Jurassic ostracod diversity. Journal of Paleontology 88, 519-530. DOI 10.1666/13-127

Cabral, M.C., Loureiro, I., Duarte, L.V. \& Azerêdo, A.C. 2013. Registo da extinção dos Metacopina (Ostracoda, Crustacea) no Toarciano de Rabaçal, região de Coimbra. Comunicações Geológicas 100, Especial I, 63-68.

Cabral, M.C., Loureiro, I.M., Pinto, S., Duarte, L.V. \& AzERÊDo, A.C. 2011. New light on the Metacopina (Crustacea, Ostracoda) Toarcian extinction event: integrated data from the Lusitanian Basin, Portugal. Geophysical Research Abstracts 13, art. EGU2011-3607.

Caruthers, A.H., Smith, P.L. \& Gröcke, D.R. 2013. The Pliensbachian-Toarcian (Early Jurassic) extinction, a global multi-phased event. Palaeogeography, Palaeoclimatology, Palaeoecology 386, 104-118. DOI 10.1016/j.palaeo.2013.05.010

Caswell, B.A., Coe, A.L. \& Cohen, A.S. 2009. New range data for marine invertebrate species across the early Toarcian (Early Jurassic) mass extinction. Journal of the Geological Society of London 166, 859-872.

DOI 10.1144/0016-76492008-0831

Comas-Rengifo, M.J., Duarte, L.V., Felix, F.F., Joral, F.G., Goy, A. \& Rocha, R.B. 2015. Latest Pliensbachian-Early Toarcian brachiopod assemblages from the Peniche section (Portugal) and their correlation. Episodes 38, 2-8. DOI 10.18814/epiiugs/2015/v38i1/001

Correia, V.F., Riding, J.B., Duarte, L.V., Fernandes, P. \& Pereira, Z. 2017. The palynological response to the Toarcian Oceanic Anoxic Event (Early Jurassic) at Peniche, Lusitanian Basin, western Portugal. Marine Micropaleontolology 137, 46-63. DOI 10.1016/j.marmicro.2017.10.004

Coryell, H.N. 1963. Bibliographic index and classification of the Mesozoic Ostracoda. 1175 pp. University of Dayton Press, Dayton.

Coryell, H.N. \& Fields, S. 1937. A Gatun Ostracode fauna from Cativa, Panama. American Museum Novitates 956, 1-18.

DANA, J.D. 1852. Crustacea: Cyproidea. United States Exploring Expedition during the Years 1838, 1839, 1840, 1841, 1842, under the Command of Charles Wilkes, U.S.N. 13(2), 1277-1304.

Danise, S., Twitchett, R.J., Little, C.T.S. \& Clémence, M.E. 2013. Marine benthic community dynamics through the Early
Toarcian (Early Jurassic) global warming event. PLoS One 8, art. e56255. DOI 10.1371/journal.pone.0056255

Dera, G., Brigaud, B., Monna, F., Laffont, R., Pucéat, E., DeConinck, J.-K., Pellenard, P., Joachimski, M.M. \& Durlet, C. 2011. Climatic ups and downs in a disturbed Jurassic world. Geology 39, 39-51. DOI 10.1130/G31579.1

DREXLER, E. 1958. Foraminiferen und Ostracoden aus dem Lias $\alpha$ von Siebeldingen/Pfalz. Geologisches Jahrbuch 75, 475-554.

Dreyer, E. 1967. Mikrofossilien des Rät und Lias von SW-Brandenburg. Jahrbuch für Geologie 1(1965), 491-531.

DuARTE, L.V. 1997. Facies analysis and sequential evolution of the Toarcian-Lower Aalenian series in the Lusitanian Basin (Portugal). Comunicações do Instituto Geológico e Mineiro 83, 65-94.

DuARTE, L.V. 2007. Lithostratigraphy, sequence stratigraphy and depositional setting of the Pliensbachian and Toarcian series in the Lusitanian Basin (Portugal). Ciências da Terra (UNL) $16,17-23$.

Duarte, L.V. \& Soares, A.F. 2002. Litostratigrafia das séries margo-calcárias do Jurássico inferior da Bacia Lusitânica (Portugal). Comunicações do Instituto Geológico e Mineiro 89, $135-154$.

Duarte, L.V., Comas-Rengifo, M.J., Hesselbo, S., Mattioli, E., Suan, G., Baker, S., Cabral, M.C., Correia, V., García Joral, F., Goy, A., Reolid, M., Rita, P., Félix, F., Paredes, R., Pittet, B. \& RochA, R.B. 2018. The Toarcian oceanic anoxic event at Peniche. An exercise in integrated stratigraphy stop 1.3, 33-54. In Duarte, L.V. \& Silva, R.L. (eds) $2^{\text {nd }}$ International Workshop on the Toarcian Oceanic Anoxic Event: Field Trip Guidebook, Coimbra, September 7th-8th, 2018-IGCP-655: The Toarcian Oceanic Anoxic Event in the Western Iberian Margin and its Context within the Lower Jurassic Evolution of the Lusitanian Basin. University of Coimbra.

Duarte, L.V., Silva, R.L., Félix, F., Comas-Rengifo, M.J., Rocha, R.B., Mattioli, E., Paredes, R., Mendonça Filho, J.G. \& Cabral, M.C. 2017. The Jurassic of the Peniche Peninsula (Portugal): scientific, educational and science popularization relevance. Revista de la Sociedad Geológica de España 30, 55-70.

Duarte, L.V., Silva, R.L., Oliveira, L.C.V., Comas-Rengifo, M.J. \& Silva, F. 2010. Organic-rich facies in the Sinemurian and Pliensbachian of the Lusitanian Basin, Portugal: Total Organic Carbon distribution and relation to transgressiveregressive facies cycles. Geologica Acta 8, 325-340.

Duarte, L.V., Wright, V.P., López, S.F., Elmi, S., Krautter, M., Azerêdo, A.C., Henriques, M.H., Rodrigues, R. \& Perilli, N. 2004. Early Jurassic carbonate evolution in the Lusitanian Basin (Portugal): Facies, sequence stratigraphy and cyclicity, 45-71. In Duarte, L.V. \& Henriques, M.H. (eds) Carboniferous and Jurassic Carbonate Platforms of Iberia. Universidade de Coimbra. 23rd International Association of Sedimentologists Meeting. Field Trip Guidebook 1.

Exton, J. 1979. Pliensbachian and Toarcian Microfauna of Zambujal, Portugal: Systematic Paleontology. Carleton University Geological Paper 79-1, 1-103.

Exton, J. \& Gradstein, F.M. 1984. Early Jurassic stratigraphy and micropalaeontology of the Grand Banks and Portugal, 
13-30. In Westermann, G.E.G. (ed.) Jurassic-Cretaceous Biochronology and Paleogeography of North America. Geological Association of Canada Special Paper 27.

Fantasia, A., Adette, T., Spangenberg, J.E., Font, E., Duarte, L.V. \& Föllmi, K.B. 2019. Global versus local processes during the Pliensbachian-Toarcian transition at the Peniche GSSP, Portugal: A multi-proxy record. Earth-Science Reviews 198, art. 102932. DOI 10.1016/j.earscirev.2019.102932

FIELD, R.A. 1966. Species of the family Cytherellidae (Ostracoda) from the Lower Lias of South Dorset, England. Senckenbergiana lethaea 47, 87-105.

Fischer, W. 1962. Ostracoden der Gattung Monoceratina Roth 1928, Cytheropteron G.O. Sars 1865 und andere im Lias zeta Schwabens. Neues Jahrbuch für Geologie und Paläontologie, Abhandlungen 114, 333-345.

Franz, M., Tesakova, E. \& Beher, E. 2009. Documentation and revision of the index ostracods from the Lower and Middle Jurassic in SW Germany according to Buck (1954). Palaeodiversity 2, 119-167.

Gómez, J.J. \& ARIAs, C. 2010. Rapid warming and ostracods mass extinction at the Lower Toarcian (Jurassic) of central Spain. Marine Micropaleontology 74, 119-135. DOI 10.1016/j.marmicro.2010.02.001

Gómez, J.J. \& Goy, A. 2011. Warming-driven mass extinction in the Early Toarcian (Early Jurassic) of northern and central Spain. Correlation with other time-equivalent European sections. Palaeogeography, Palaeoclimatology, Palaeoecology 306, 176-195. DOI 10.1016/j.palaeo.2011.04.018

Gómez, J.J., Goy, A. \& CANAles, M.L. 2008. Seawater temperature and carbon isotope variations in belemnites linked to mass extinction during the Toarcian (Eartly Jurassic) in Central and Northern Spain. Comparison with other European sections. Palaeogeography, Palaeoclimatology, Palaeoecology 258, 28-58. DOI 10.1016/j.palaeo.2007.11.005

Gradstein, F.M., OGG, J.G., Schmitz, M.D. \& OGG, G.M. (eds) 2012. The Geological Timescale 2012. 1176 pp. Elsevier B.V.

Gramann, F. 1963. Liasina n. gen. (Ostracoda) aus dem Deutschen Lias. Geologisches Jahrbuch 82, 65-73.

Gründel, J. 1964. Zur gattung Healdia (Ostracoda) und zu einigen verwandten formen aus dem Unteren Jura. Geologie $13,456-477$.

GrÜNDEL, J. 1967. Zur Großgliederung der Ordnung Podocopida G.W. Müller, 1894 (Ostracoda). Neues Jahrbuch für Geologie und Paläontologie, Monatshefte 1967, 321-332.

Gründel, J. \& Kozur, H. 1972. Zur taxonomie der Bythocytheridae und Tricornidae (Podocopida, Ostracoda). Monatsberichte der Deutschen Akademie der Wissenschaften zu Berlin 13 (for 1971), 907-937.

Hallam, A. 1961. Cyclothems, Transgressions and Faunal Change in the Lias of North-West Europe. Transactions of the Edinburgh Geological Society 18, 124-174.

DOI 10.1144/transed.18.2.124

Harlton, B.H. 1933. Micropaleontology of the Pennsylvanian Johns Valley Shale of the Ouachita Mountains, Oklahoma, and its relationship to the Mississippian Caney Shale. Journal of Paleontology 7, 3-29.

Herrig, E. 1979. Die Gattung Bairdia (Ostracoda, Crustacea) im Lias von Thüringen. Teil I. Zeitschrift für Geologische Wissenschaften 7, 641-661.

Herrig, E. 1985. Zur Taxonomie und Evolution der Gattung Kinkelinella Martin, 1960 (Ostracoda) im Unteren Jura von Mittel- und Nordwesteuropa. Zeitschrift für Geologische Wissenschaften 13, 715-723.

Hesselbo, S.P., Jenkyns. H.C., Duarte, L.V. \& Oliveira, L.C.V. 2007. Carbon-isotope record of the Early Jurassic (Toarcian) Oceanic Anoxic Event from fossil wood and marine carbonate (Luistanian Basin, Portugal). Earth and Planetary Science Letters 253, 455-470. DOI 10.1016/j.eps1.2006.11.009

IssLER, A. 1908. Beiträge zur Stratigraphie und Mikrofauna des Lias in Schweben. Palaeontographica 55, 1-104.

Jenkyns, H.C. 1985. The Early Toarcian and CenomanianTuronian anoxic events in Europe: comparisons and contrasts. Geologisches Rundschau 74, 505-518.

DOI 10.1007/BF01821208

JENKYns, H.C. 1988. The early Toarcian (Jurassic) anoxic event: stratigraphic, sedimentary, and geochemical evidence. American Journal of Science 288, 101-151. DOI 10.2475/ajs.288.2.101

JenKYns, H.C. 2010. Geochemistry of oceanic anoxic events. Geochemistry, Geophysics, Geosystems 11, art. Q03004. DOI 10.1029/2009GC002788

Jones, T.R. 1849. A monograph of the Entomostraca of the Cretaceous Formation of England. Annual Volumes (Monographs) of the Palaeontographical Society 3, 1-40. DOI 10.1080/02693445.1850.12088362

Jones, T.R. \& Sherborn, C.D. 1888. On some Ostracoda from the Fullers-earth Oolite and Bradford Clay. Proceedings of the Bath Natural History and Field Club 6, 249-278.

Kaufmann, A. 1900. Cypriden und Darwinuliden der Schweiz. Revue Suisse de Zoologie 8, 209-423. DOI 10.5962/bhl.part.10584

KNitTER, H. 1983. Biostratigraphische Untersuchungen mit Ostracoden im Toarcien Süddeutschlands. Facies 8, 213-262. DOI 10.1007/BF02536743

KNitTer, H. \& Riegraf, W. 1984. Biostratigraphie (Cephalopoden, Ostracoden) des Oberen Toarcium von Blumberg-Achdorf/ Wutach und Weilheim/Teck (Baden-Württemberg). Jahrbuch des Geologisches Landesamt Baden-Württemberg 26, 57-97.

Kollmann, K. 1960. Ostracoden aus der Alpinen Trias Österreichs - 1: Parabairdia n.g. und Ptychobairdia n.g. (Bairdiidae). Jahrbuch der Geologischen Bundesanstalt, Sonderband 5, 79-105.

Korte, C., Hesselbo, S.P., Ullmann, C.V., Dietl, G., Ruhl, M., Schweigert, G. \& Thibault, N. 2015. Jurassic climate mode governed by ocean gateway. Nature Communications 6, art. 10015. DOI 10.1038/ncomms10015

Kozur, H. 1972. Die Bedeutung triassischer Ostracoden für stratigraphische und paläoökologische Untersuchungen. Mitteilungen der Gesellschaft der Geologie und Bergbaustudenten in Oesterreich 21, 623-660.

Kristan-Tollmann, E. 1977. Zur Evolution des Schließmuskelfeldes bei Healdiidae und Cytherellidae (Ostracoda). Neues Jahrbuch für Geologie und Paläontologie, Monatshefte 1977, 621-639. 
Kristan-Tollmann, E. 1993. Zur paläogeographischen Verbreitung der Ostracoden-Gattung Hermiella an der Rhät/LiasGrenze. Zitteliana 20, 331-342.

Latreille, P.A. 1806. Genera Crustaceorum et Insectorum secundum ordinem naturalem in familias disposita. $302 \mathrm{pp}$. Amand Koenig, Paris. DOI 10.5962/bhl.title.5093

Little, C.T.S. \& Benton, M.J. 1995. Early Jurassic mass extinctions: a global long-term event. Geology 23, 495-498. DOI 10.1130/0091-7613(1995)023<0495:EJMEAG >2.3.CO;2

Littler, K., Hesselbo, S.P. \& Jenkyns, H.C. 2010. A carbonisotope perturbation at the Pliensbachian-Toarcian boundary: evidence from the Lias Group, NE England. Geological Magazine 147, 181-192. DOI 10.1017/S0016756809990458

LuUbimova, P.S. 1955. Ostrakody Mezozoyskikh otlozheniy srednego Povolzhya i Obshchego Syrta. Trudy Vsesoyuznogo Neftyango Nauchno-Issledovatelskogo Geologo-razvedochnogo Instituta (VNIGRI), Novaya Seriya 84, 3-189.

LoRD, A.R. 1982. Metacopine ostracods in the Lower Jurassic, 262-277. In Banner, F.T. \& Lord, A.R. (eds) Aspects of Micropalaeontology. George Allen and Unwin, London. DOI 10.1007/978-94-011-6841-0_7

Lord, A. \& Moorley, A. 1974. On Ogmoconcha ambo Lord and Moorley sp. nov. A Stereo-Atlas of Ostracod Shells 2, 9-16.

Lord, A.R., Cabral, M.C. \& Danielopol, D.L. 2020. Sievetype normal pore canals in Jurassic ostracods: A review with description of a new genus. Acta Palaeontologica Polonica 65, 37 pp. DOI 10.4202/app.00632.2019

Malz, H. 1971. Zur Taxonomie 'glattschaliger' Lias-Ostracoden. Senckenbergiana lethaea 52, 433-455.

Mandelstam, M.I. 1959. Ostrakody iz otlozheniy Paleogena sredney Azii. Trudy Vsesoyuznogo Neftyango Nauchno-Issledovatelskogo Geologo-razvedochnogo Instituta (VNIGRI), Novaya Seriya 136 (Mikrofauna SSSR: 10), 442-542.

Mandelstam, M.I. 1960. In Orlov, Y.A. (ed.) Osnovy Paleontologii 8, 365-411.

Martin, G.P.R. 1960. In Hoffmann, K. \& Martin, G.P.R. Die zone des Dactylioceras tenuicostatum (Toarcien, Lias) in NW- und SW-Deutschland. Paläontologische Zeitschrift 34, 103-149. DOI 10.1007/BF02987046

Mattioli, E., Pittet, B., Petitpierre, L. \& Mailliot, S. 2009. Dramatic decrease of pelagic carbonate production by nannoplankton across the Early Toarcian anoxic event (TOAE). Global and Planetary Change 65(3-4), 134-145. DOI 10.1016/j.gloplacha.2008.10.018

M'Coy, F. 1844. A synopsis of the characters of the Carboniferous Limestone fossils of Ireland. 207 pp. University Press, Dublin. DOI 10.5962/bhl.title.11559

McKenzIE, K.G. 1968. Saipanetta, new name for Saipanella McKenzie, 1967 (Ostracoda, Podocopida) non Saipanella Chamberlin, 1945 (Myriopoda). Crustaceana 14, 104-105. DOI 10.1163/156854068X00674

Monostori, M. 2008. Comparative study of the Pliensbachian and Toarcian ostracods in the Gerecse and Mecsek Mountains, Hungary. Hantkeniana 6, 17-31.

Mouterde, R. 1955. Le Lias de Peniche. Comunicações dos Serviços Geológicos de Portugal 36, 87-115.

MülLer, G.W. 1894. Die Ostracoden des Golfes von Neapel und der angrenzenden Meeres-Abschnitte. Fauna und Flora des Golfes von Neapel und der angrenzenden Meeres-Abschnitte. Herausgegeben von der Zoologischen Station zu Neapel 21, $1-404$.

Müller, G.W. 1912. Ostracoda in das Tierreich. Das Tierreich $31,1-434$.

Norman, A.M. 1865. Report on the Crustacea of the deep sea dredging off the coasts of Northumberland and Durham. Transactions of the Natural History Society of Northumberland, Durham and Newcastle-upon-Tyne 1, 12-19.

OGg, J., OGg, G. \& Gradstein, F. 2016. A Concise Geologic Time Scale. 240 pp. Elsevier.

Olempska, E., Horne, D.J. \& Szaniawaski, H. 2012. First record of preserved soft parts in a Palaeozoic podocopid (Metacopina) ostracod, Cytherellina submagna: phylogenetic implications. Proceedings of the Royal Society of London B, 279, 564-570. DOI 10.1098/rspb.2011.0943

Pais, V., Cabral, M.C., Lord, A., Azerêdo, A.C. \& Gallagher, L. 2016. Middle Jurassic Tethyan-Boreal ostracod faunal links: a case study from the Callovian of Portugal. Journal of Micropalaeontology 35, 205-228.

DOI 10.1144/jmpaleo2015-035

Pinto, S. 2008. Ostracodos do Toarciano da Bacia Lusitânica (Peniche e Alvaiázere). 202 pp. Master thesis, Universidade de Lisboa, Faculdade de Ciências, Departamento de Geologia, Portugal.

Pinto, S., Cabral, M.C. \& Duarte, L.V. 2007. Preliminary data on the ostracod fauna from the Lower Toarcian of Peniche. Ciências da Terra (UNL) 16, 37-43.

Pittet, B., Suan, G., Lenoir, F., Duarte, L.V. \& Mattioli, E. 2014. Carbon isotope evidence for sedimentary discontinuities in the Lower Toarcian of the Lusitanian Basin (Portugal): sea level change at the onset of the Oceanic Anoxic Event. Sedimentary Geology 303, 1-14. DOI 10.1016/j.sedgeo.2014.01.001

Quenstedt, F.A. 1858. Der Jura. 842 pp. Tübingen, Laupp \& Siebeck.

Richter, H. 1987. Die Mikrofauna des Unteren Toarciums der Nordschweiz. Neues Jahrbuch für Geologie und Paläontologie, Abhandlungen 176, 137-155.

Riegraf, W. 1984. Neue Ostracoden-Arten aus dem Oberen Pliensbachium und Unteren Toarcium Südwestdeutschlands und Südfrankreichs. Stuttgarter Beiträge zur Naturkunde B, 104, 1-19.

Riegraf, W. 1985. Mikrofauna, Biostratigraphie und Fazies im Unteren Toarcium Südwestdeutschlands und Vergleiche mit benachbarten Gebieten. Tübinger Mikropaläontologische Mitteilungen 3, 1-232.

Rita, P., Reolid, M. \& Duarte, L.V. 2016. Benthic foraminiferal assemblages record major environmental perturbations during the Late Pliensbachian-Early Toarcian interval in the Peniche GSSP, Portugal. Palaeogeography, Palaeoclimatology, Palaeoecology 454, 267-281.

DOI 10.1016/j.palaeo.2016.04.039

Rocha, R.B., Mattioli, E., Duarte, L.V., Pittet, B., Elmi, S., Mouterde, R., Cabral, M.C., Comas-Rengifo, M.J., Gómez, J.J., Goy,A., Hesselbo, S.P., Jenkyns, H.C., Littler, K., Mailliot, S., 
Oliveira, L.C.V., Osete, M.L., Perilli, N., Pinto, S., Ruget, C. \& SuAn, G. 2016. Base of the Toarcian Stage of the Lower Jurassic defined by the Global Boundary Stratotype Section and Point (GSSP) at the Peniche section (Portugal). Episodes 39, 460-481. DOI 10.18814/epiiugs/2016/v39i3/99741

Rodríguez-Tovar, F.J., Miguez-Salas, O. \& Duarte, L.V. 2017. Toarcian Oceanic Anoxic Event induced unusual behaviour and palaeobiological changes in Thalassinoides tracemaker. Palaeogeography, Palaeoclimatology, Palaeoecology 485, 46-56. DOI 10.1016/j.palaeo.2017.06.002

Roemer, F.A. 1841. Die versteinerungen des Norddeutschen Kreidegebirges. 145 pp. Hannover. DOI 10.5962/bhl.title.44865

Rотн, R. 1928. Monoceratina: a new genus of Ostracoda from the Pennsylvanian of Oklahoma. Journal of Paleontology 2, $15-19$.

Ruebsam, W., Mayer, B. \& Schwark, L. 2019. Cryosphere carbon dynamics control early Toarcian global warming and sea level evolution. Global and Planetary Change 172, 440-453. DOI 10.1016/j.gloplacha.2018.11.003

SARS, G.O. 1866. Oversigt af Norges marine ostracoder. Forhandlinger $i$ Videnskabs-selskebet $i$ Christiania 1865, 1-130.

SARs, G.O. 1887. Nye bidrag til kundskaben om Middelhavets invertebratfauna: 4. Ostracoda Mediterranea (Sydeuropaeiske). Archiv for Mathematik og Naturvidenskab 12, 173-324. DOI 10.5962/bhl.title.10252

SARS, G.O. 1926. An account of the Crustacea of Norway with short descriptions and figures of all the species. Volume 9, parts 13-14. 209-240 pp. Bergen Museum, Bergen.

Schmid-Röhl, A., Röhl, H.J., Oschmann, W., Frimmel, A. \& SchWARK, L. 2002. Palaeoenvironmental reconstruction of Lower Toarcian epicontinental black shales (Posidonia Shale, SW Germany): global versus regional control. Geobios 35, 13-20. DOI 10.1016/S0016-6995(02)00005-0

Shaver, R.H. 1961. In Benson, R.H. et al. Systematic Descriptions, Q99-Q414. In Moore, R.C. (ed.) Treatise on Invertebrate Paleontology, Q. Arthropoda 3, Crustacea, Ostracoda. Geological Society of America, New York.

Stephenson, M.B. 1946. Weches Eocene Ostracoda from Smithville, Texas. Journal of Paleontology 20, 297-344.

Suan, G., Mattioli, E., Pittet, B., Lécuyer, C., Suchéras-MarX, B., Duarte, L.V., Philippe, M., Reggiani, L. \& Martineau, F. 2010. Secular environmental precursors to Early Toarcian (Jurassic) extreme climate changes. Earth and Planetary Science Letters 290, 448-458. DOI 10.1016/j.eps1.2009.12.047
Suan, G., Mattioli, E., Pittet, B., Mailliot, S. \& Lécuyer, C. 2008. Evidence for major environmental perturbation prior to and during the Toarcian (Early Jurassic) oceanic anoxic event from the Lusitanian Basin, Portugal. Paleoceanography 23, art. PA1202. DOI /10.1029/2007PA001459

Sylvester-Bradley, P.C. 1961. In Benson, R.H. et al. Systematic Descriptions, Q99-Q414. In Moore, R.C. (ed.) Treatise on Invertebrate Paleontology, Q. Arthropoda 3, Crustacea, Ostracoda. Geological Society of America, New York.

Tate, R. \& Blake, J.F. 1876. The Yorkshire Lias. 475 pp. John Van Voorst, London.

Trecalli, A., Spangenberg, J., Adatte, T., Föllmi, K.B. \& Parente, M. 2012. Carbonate platform evidence of ocean acidification at the onset of the early Toarcian oceanic anoxic event. Earth and Planetary Science Letters 357, 214-225. DOI 10.1016/j.eps1.2012.09.043

Triebel, E. 1941. Zur Morphologie und Ökologie der fossilen Ostracoden. Mit beschreibung einiger neuer gattungen und arten. Senckenbergiana 23, 294-400.

Triebel, E. 1950. Die taxonomische Stellung dere OstracodenGattung Ogmoconcha und der Lectotypus von O. amalthei. Senckenbergiana 31, 113-120.

Triebel, E. \& Bartenstein, H. 1938. Die Ostracoden des deutschen Juras. I. Monoceratina-Arten aus dem Lias und Dogger. Senckenbergiana 20, 502-518.

VAn Den Bold, W.A. 1960. Eocene and Oligocene Ostracoda of Trinidad. Micropaleontology 6, 145-196. DOI $10.2307 / 1484466$

Wright, V.P. \& Wilson, R.C.L. 1984. A carbonate submarinefan sequence from the Jurassic of Portugal. Journal of Sedimentary Petrology 54, 394-412. DOI 10.1306/212F8427-2B24-11D7-8648000102C1865D

Xu, W., Ruhl, M., Jenkyns, H.C., Hesselbo, S.P., Riding, J.B., Selby, D., NaAfs, B.D.A., Weijers, J.W.H., Pancost, R.D., TegelaAr, E.W. \& Idiz, E.F. 2017. Carbon sequestration in an expanded lake system during the Toarcian Oceanic Anoxic Event. Nature Geoscience 10, 129-134. DOI 10.1038/ngeo2871

Xu, W., Ruhl, M., Jenkyns, H.C., Leng, M.J., Huggett, J.M., Minisini, D., Ullmann, C.V., Riding, J.B., Weijers, J.W.H., Storm, M.S., Percival, L.M.E., Tosca, N.J., Idiz, E.F., Tegelaar, E.W. \& Hesselbo, S.P. 2018. Evolution of the Toarcian (Early Jurassic) carbon-cycle and global climatic controls on local sedimentary processes (Cardigan Bay Basin, UK). Earth and Planetary Science Letters 484, 396-411. DOI 10.1016/j.eps1.2017.12.037 